Article

\title{
Demineralization, Collagen Modification and Remineralization Degree of Human Dentin after EDTA and Citric Acid Treatments
}

\author{
Maria Giovanna Gandolfi ${ }^{1}$, Paola Taddei ${ }^{2}{ }^{\mathbb{C}}$, Anna Pondrelli ${ }^{1}{ }^{\mathbb{C}}$, Fausto Zamparini ${ }^{1}{ }^{\mathbb{C}}$, \\ Carlo Prati $^{3, *}$ and Gianrico Spagnuolo ${ }^{4,5}$ \\ 1 Laboratory of Biomaterials and Oral Pathology, Dental School, Department of Biomedical and NeuroMotor \\ Sciences, University of Bologna, 40126 Bologna, Italy; mgiovanna.gandolfi@unibo.it (M.G.G.); \\ anna.pondrelli@studio.unibo.it (A.P.); fausto.zamparini2@unibo.it (F.Z.) \\ 2 Biochemistry Unit, Department of Biomedical and NeuroMotor Sciences, University of Bologna, \\ 40126 Bologna, Italy; paola.taddei@unibo.it \\ 3 Endodontic Clinical Section, Dental School, Department of Biomedical and NeuroMotor Sciences, University \\ of Bologna, 40126 Bologna, Italy \\ 4 Department of Neuroscience and Reproductive and Odontostomatological Sciences, University of Napoli \\ “Federico II", 80131 Napoli, Italy; gianrico.spagnuolo@gmail.com \\ 5 Institute of Dentistry, I. M. Sechenov First Moscow State Medical University, 119146 Moscow, Russia \\ * Correspondence: carlo.prati@unibo.it
}

Received: 22 November 2018; Accepted: 18 December 2018; Published: 21 December 2018

\begin{abstract}
The aim of the study was to investigate the effects of several decalcifying agents used as irrigant solutions in endodontic treatment on collagen and mineral components of dentin. Coronal dentin discs from five caries-free human third molars with a smear layer were treated for one minute with a chelating solution (1\% Ethylenediaminetetraacetic acid (EDTA), 10\% EDTA, 17\% EDTA, $10 \%$ citric acid). Mineralization degree $\left(\mathrm{Ca} / \mathrm{N}\right.$ and $\mathrm{P} / \mathrm{N}$ atomic ratios, IR $I_{\text {apatite }} / I_{\text {amide II }}$ and $I_{1410 \text { (carbonate) }} / I_{554 \text { (phosphate) }}$ spectroscopic ratios) and possible collagen rearrangements (collagen infrared (IR) amide II e III shifts) were evaluated by environmental scanning electron microscopy (ESEM)/energy dispersive X-ray spectroscopy (EDX) and IR spectroscopy before and after treatment (T0) and after ageing (T24h and $\mathrm{T} 2 \mathrm{~m}$ ) in simulated body fluid (SBF). At T0, analysis showed that the highest demineralizing effect was achieved using a 10\% citric acid solution and 10\% EDTA, while the smallest effect was observed when using 17\% EDTA. No significant collagen modifications were detected upon treatment with 1\% EDTA, while subtle changes were observed after the other treatments. At T24h or T2m, analyses showed the highest remineralization values for $1 \%$ EDTA and the lowest for $10 \%$ citric acid, mainly at $\mathrm{T} 2 \mathrm{~m}$. The samples treated with 17\% EDTA showed slight collagen rearrangements upon remineralization. In conclusion, the highest demineralizing effect was observed for 10\% EDTA and 10\% citric acid. Collagen rearrangement was found for all the treatments except for 1\% EDTA. The highest remineralization capability in SBF values was recorded for $1 \%$ EDTA and the lowest for 10\% citric acid. A slight collagen rearrangement upon remineralization was still present in 17\% EDTA-treated samples. Clinical use as a chelating agent in the endodontic therapy of citric acid and concentrated EDTA solutions should be reconsidered.
\end{abstract}

Keywords: EDTA; citric acid; collagen modification; mineralization degree; chelating agents; $\mathrm{Ca} / \mathrm{P}$ atomic ratio; $\mathrm{Ca} / \mathrm{N}$ atomic ratio; $\mathrm{P} / \mathrm{N}$ atomic ratio 


\section{Introduction}

Dentine is a complex tissue which contains collagen and other proteins, apatite as the mineral phase, and water. Dentine treatments with manual or NiTi rotary root canal instruments generate a smear layer [1-4], an amorphous irregular thin layer composed of both organic and inorganic components. This smear layer may be attached to the dentinal surface and forced into the dentinal tubules, forming intratubular plugs [5,6]. In endodontics, the smear layer covers the root canal walls and occludes the orifices of the dentinal tubules $[1,7,8]$ preventing the complete sterilization of the canals and an appropriate seal. In order to have a complete removal of the smear layer, chelating agents are routinely used in endodontics.

Ethylenediaminetetraacetic acid (EDTA) and citric acid solutions are the most common chelating agents currently used for root canal treatment and are able to demineralize dentine by combining with calcium ions of the dentine structure [9]. EDTA is considered the most effective chelating agent in endodontic therapy, showing the ability to very effectively remove the inorganic component, especially in the coronal and middle third of the canal [9-11]. Similarly, citric acid solutions-at concentrations ranging from $1 \%$ to $50 \%$-are used to remove both the superficial smear layer and intratubular smear plugs [12-16].

Despite the wide clinical use of EDTA and citric acid solutions, no information is present regarding their activity on both organic and inorganic components. In particular, collagen rearrangement/ modifications produced by EDTA and citric acid solutions have been never investigated. Clinically, prolonged activity of residual chelating agents on the inorganic dentine structure may lead to apical leakage $[17,18]$ and reduced tooth microhardness, finally resulting in endodontic failures and root fractures.

Different techniques allow for analysis of the samples in a non-destructive way and without invasive measurements, including Fourier transform infrared spectroscopy (FTIR) with attenuated total reflectance (ATR) [19-21] and environmental scanning electron microscopy (ESEM) with energy dispersive X-ray spectrometry (EDX) [22,23]. Together, these techniques may be useful for analyzing the changes in the degree of dentine mineralization and the collagen modifications after chemical treatments.

In complex biological systems, such as dentine, the IR spectrum is the sum of the contributions gathered mainly from collagen and apatite phases [23]. The intensities of IR absorption bands provide quantitative information about the sample contents, depending on the nature of the molecular bonds, their structure, and their environment [22]. Previous investigations have used IR spectroscopy to study dentine collagen mineralization [22,24-26] and useful spectroscopic markers have been identified to determine the changes in the apatite/collagen ratio [22,24].

ESEM enables the examination of soft, hydrated, unfixed, and uncoated surfaces, i.e., bulk biological tissues in their "natural" state, providing a great advantage for the studies in the biological field $[27,28]$. X-ray microprobe and EDX mapping allow for the identification of different mineralizing zones and the mapping of the demarcation between the mineralizing and the mineralized areas $[20,22,23]$. The evaluation of $\mathrm{Ca} / \mathrm{N}$ and $\mathrm{P} / \mathrm{N}$ ratios proved to be a useful method to evaluate the degree of mineralization of the organic matrix of dentine [20,22,23].

The present study was aimed at assessing the dentine de-remineralization process and the collagen rearrangement after treatment with different chelating acids (EDTA solutions and citric acid solution) and after immersion in simulated body fluid (SBF) for $24 \mathrm{~h}$ and two months. In particular, the Ca/N and $\mathrm{P} / \mathrm{N}$ ratios calculated by EDX and IR spectroscopic markers were used to evaluate the degree of mineralization of the organic matrix of dentine.

\section{Materials and Methods}

\subsection{Dentine Preparation and Treatment}

Five dentine discs were prepared from the middle third of coronal human caries-free molars extracted for surgical reasons from healthy patients. The root and the occlusal enamel were removed 
from each tooth to obtain 2.0-0.5 mm-thick crown segments. The removal of pulpal tissue was performed with small forceps, taking care not to touch the predentine surface and the inner part of the pulpal chamber. After preparation of the dentine discs, each one was divided into four slices; two for the EDX analyses and two for the attenuated total reflectance (ATR)-Fourier transform infrared (FTIR) analyses. One slice was analyzed after the treatments and after 24 months, while the other slice was prepared and stored for two months. The upper dentine surface of each slice was sanded with wet 600 -grit $\mathrm{SiC}$ abrasive paper for $30 \mathrm{~s}$ to create a standard flat dentine surface covered by a standardized smear layer (SL) $[29,30]$. Each dentine slice surface $(n=4$ for each tooth) was then treated with $1 \mathrm{~mL}$ of one of the different chelating agents, namely EDTA $(1 \%, 10 \%, 17 \%)$ or citric acid $10 \%$ (positive control group) or with distilled water (negative control group) for $1 \mathrm{~min}$, see Table 1 . The $\mathrm{pH}$ of each tested solution has been measured using a selective temperature-compensated electrode (Sen Tix Sur WTW, Weilheim, Germany) connected to a multi-parameter laboratory meter (InoLab 750 WTW, Weilheim, Germany) previously calibrated with standard solutions.

Each dentine slice was then rinsed with distilled water and soaked in SBF, whose composition was $\mathrm{Ca}^{++} 1.27 \mathrm{mM}, \mathrm{Cl}^{-} 144.7 \mathrm{mM}, \mathrm{K}^{+} 5.8 \mathrm{mM}, \mathrm{Na}^{+} 141.6 \mathrm{mM}, \mathrm{Mg}^{++} 0.81 \mathrm{mM}, \mathrm{HCO}_{3}^{-} 4.17 \mathrm{mM}$, $\mathrm{SO}_{4}{ }^{2-} 0.81 \mathrm{mM}, \mathrm{H}_{2} \mathrm{PO}_{4}{ }^{-} 0.44 \mathrm{mM}$, and $\mathrm{HPO}_{4}{ }^{2-} 0.336 \mathrm{mM}$. At each experimental time, i.e., after the SL formation, after chelating agent application, after $24 \mathrm{~h}$, and after two months of aging in SBF, the samples were tested for mineralization degree by EDX and ATR-FTIR and for surface morphology by ESEM. At each evaluation time, three measurements by both ESEM/EDX and ATR-FTIR were made on each dentine slice.

Table 1. Tested chelating agents.

\begin{tabular}{|c|c|c|}
\hline Treatments & Manufacturing & Components \\
\hline $1 \%$ EDTA & $\begin{array}{c}\text { Experimental solution obtained by } \\
\text { dilution of Tubuliclean } 10 \% \text { with } \\
\text { distilled water }\end{array}$ & $\begin{array}{l}\text { 1\% ethylenediaminetetraacetic acid in } \\
\text { deionized water, } \mathrm{pH} 7.4\end{array}$ \\
\hline $\begin{array}{c}10 \% \text { EDTA } \\
\text { (Tubuliclean } 10 \% \text { ) }\end{array}$ & OGNA (Muggiò, MI, Italy) & $\begin{array}{l}10 \% \text { ethylenediaminetetraacetic acid } \\
\text { (EDTA) buffered at neutral } \mathrm{pH}, \mathrm{pH} 6.8\end{array}$ \\
\hline $\begin{array}{c}17 \% \text { EDTA } \\
\text { (Germ EDTA 17\%) }\end{array}$ & GermDental (Kerr, Scafati, SA, Itay) & $\begin{array}{l}\text { 17\% ethylenediaminetetraacetic acid } \\
\text { (EDTA), pH } 9.9\end{array}$ \\
\hline 10\% Citric acid & $\begin{array}{l}\text { Experimental solution obtained by the } \\
\text { solubilization of } 99 \% \text { citric acid } \\
\text { monohydrate (Sigma Aldrich, Saint } \\
\text { Louis, MO, USA) in distilled water }\end{array}$ & $\begin{array}{l}10 \% \text { citric acid monohydrate in } \\
\text { deionized water, } \mathrm{pH} 1.8\end{array}$ \\
\hline
\end{tabular}

\subsection{ESEM/EDX Analysis}

At each step of the study, the dentine surfaces were examined using an environmental scanning electron microscope (ESEM, Zeiss EVO 50; Carl Zeiss, Oberkochen, Germany) connected to a secondary electron detector for energy dispersive X-ray analysis (EDX; Oxford INCA 350 EDS, Abingdon, UK) using computer-controlled software (Inca Energy Version 18). The uncoated surfaces were examined at low vacuum (100 Pascal), $20 \mathrm{kV}$ accelerating voltage, $8.5 \mathrm{~mm}$ working distance, $0.5 \mathrm{wt} \%$ detection level, $133 \mathrm{eV}$ resolution, 100 microseconds amplification time, measuring time: $600 \mathrm{~s}$ for element mapping and $60 \mathrm{~s}$ for spectra. EDX microchemical analysis with a ZAF correction method was carried out ( $n=3$ per sample) at random in full frame to analyze entire areas of approximately $50 \times 50 \mu \mathrm{m}$ to evaluate the relative element content (weight $\%$ and atomic \%). The $\mathrm{Ca} / \mathrm{N}$ and $\mathrm{P} / \mathrm{N}$ ratios were calculated from the data to evaluate the degree of mineralization of the dentine surfaces; the $\mathrm{Ca} / \mathrm{P}$ ratio was calculated to characterize the mineral phase [23]. 


\subsection{FT-IR Analysis}

The same dentine samples that were analyzed by EDX were submitted for ATR-IR surface analyses by a Bruker Alpha (Bruker Optik GmbH, Ettlingen, Germany) Fourier-Transform FT-IR spectrometer in ATR mode with a diamond inner reflection element (IRE). The $I_{\text {apatite }} / I_{\text {amide II }}$ and $I_{1410 \text { (carbonate) }} / I_{554 \text { (phosphate) }}$ absorbance ratios were calculated as peak heights by using the Jasco Spectra analysis software (Jasco Inc., Easton, MD, USA), version 1.53.03. At least three spectra were recorded for each sample at each step of the study. Average spectra were shown; $I_{\text {apatite }} / I_{\text {amide II }}$ and $I_{1410 \text { (carbonate) }} / I_{554 \text { (phosphate) }}$ values were reported as mean values \pm standard deviation.

The reduction of the $I_{\text {apatite }} / I_{\text {amide II }}$ ratio indicated the occurrence of a demineralization, with the weakening of the apatite bands compared to those of collagen while increasing the ratio indicated a remineralization. The changes in the $I_{1410 \text { (carbonate) }} / I_{554 \text { (phosphate) }}$ ratio assessed the carbonate content of the B-type carbonated apatite. The shifts of the collagen bands (Amide II e III) allowed for evaluation of the collagen rearrangements. Under the used experimental conditions, the penetration into the sample thickness was about $2 \mu \mathrm{m}$.

\subsection{Statistical Analysis}

The data (expressed as mean \pm standard deviation) were analyzed using one-way analysis of variance (ANOVA) for repeated measurements followed by a repeated measures (RM) Student-Newman-Keuls test among evaluation times and two-way ANOVA followed by an RM Student-Newman-Keuls test among solutions. The statistical significance was set at $p<0.05$.

\section{Results}

After sanding the surface with abrasive paper, ESEM showed a uniform and homogeneous smear layer covering the tubules, see Figures 1a, 2a, 3a, 4a, and 5a, and high peaks of calcium (Ca), phosphorous $(\mathrm{P})$, and oxygen $(\mathrm{O})$ were detected by EDX analysis; also nitrogen $(\mathrm{N})$ and carbon $(\mathrm{C})$ were found, as shown in Figures $1 b, 2 b, 3 b, 4 b$, and $5 b$. The $\mathrm{Ca} / \mathrm{N}$ ratio ranged between $0.72 \pm 0.05$ and $1.09 \pm 0.06$, see Figures $1 c, 2 c, 3 c, 4 c, 5 d$, and Table 2 ; the $\mathrm{P} / \mathrm{N}$ ratio was comprised between $0.53 \pm$ 0.06 and $0.79 \pm 0.03$, see Figures $1 c, 2 c, 3 c, 4 c, 5 d$, and Table 3 . The $\mathrm{Ca} / \mathrm{P}$ ratio ranged between 1.27 \pm 0.01 and $1.38 \pm 0.03$, see Figures $1 c, 2 c, 3 c, 4 c, 5 d$, and Table 4 . The IR spectra of the SL samples showed bands typical of collagen and B-type carbonated apatite, see Figures 6-10, at wavenumber values similar to those found for sound dentine [22,24].

To evaluate the relative apatite/collagen ratio, the IR $I_{\text {apatite }} / I_{\text {amide II }}$ ratio absorbance ratio was calculated, where $I_{\text {apatite }}$ is the absorbance of the main apatite band (i.e., the $v_{3} \mathrm{PO}_{4}{ }^{3-}$ mode at about $1000 \mathrm{~cm}^{-1}$ [31]), while $I_{\text {amide II }}$ is the absorbance of the Amide II collagen band.

According to the literature [32,33], the carbonate content of the B-type carbonated apatite phase was assessed using the IR $I_{1410 \text { (carbonate) }} / I_{554 \text { (phosphate) }}$ ratio, where $I_{1410 \text { (carbonate) }}$ and $I_{554 \text { (phosphate) }}$ are the absorbances of the main carbonate band and $v_{4} \mathrm{PO}_{4}{ }^{3-}$ mode, respectively. The values of these ratios are reported in Figure 11.

As expected, no significant differences in the $I_{\text {apatite }} / I_{\text {amide II }}$ and $I_{1410 \text { (carbonate) }} / I_{554 \text { (phosphate) }}$ ratios, see Figure 11, as well as in the $\mathrm{Ca} / \mathrm{N}, \mathrm{P} / \mathrm{N}$ and $\mathrm{Ca} / \mathrm{P}$ ratios, see Tables $2-4$, were observed among the sanded samples (SL) corresponding to the different treatments. 

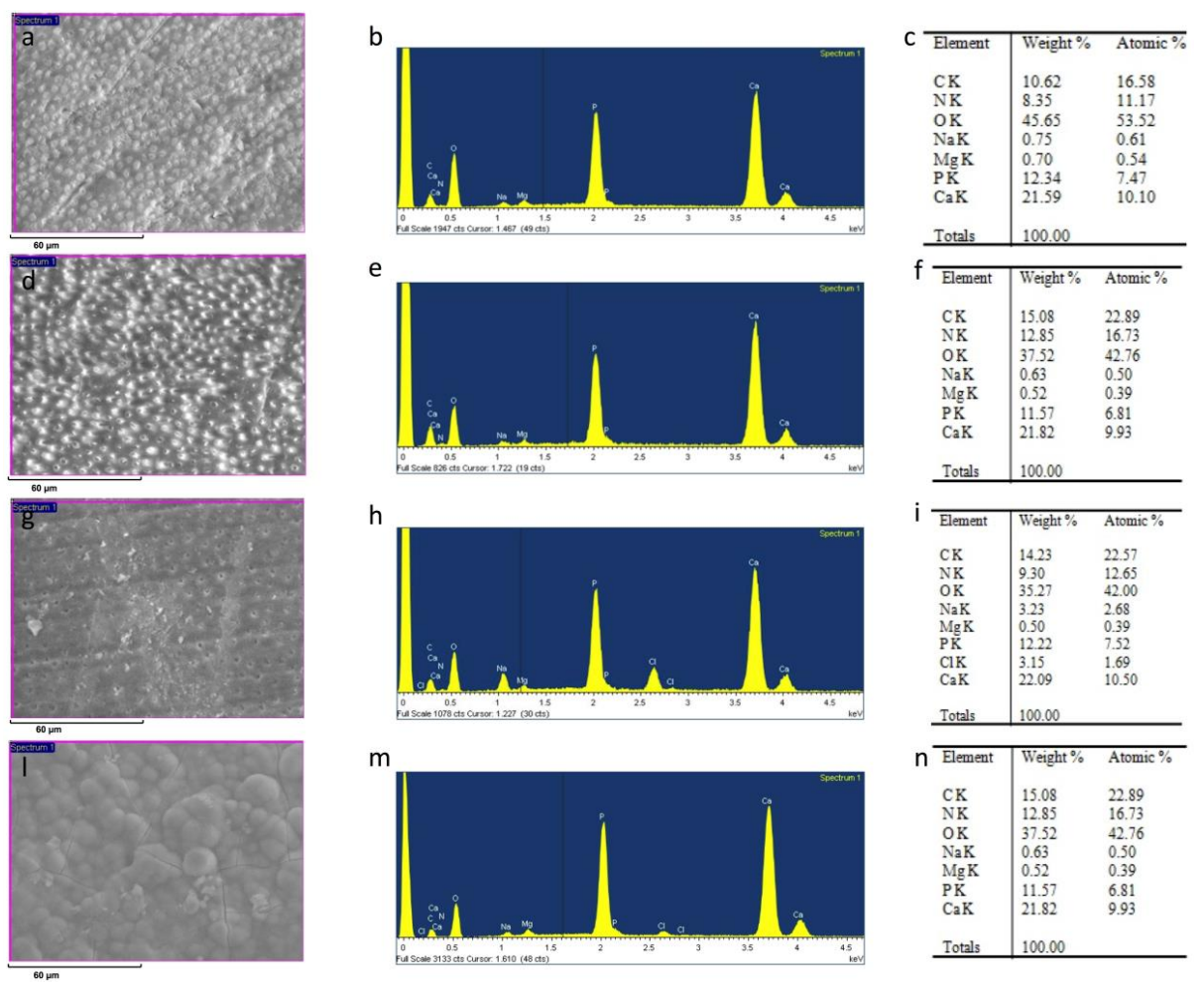

Figure 1. ESEM image, EDX spectra, and table of elements recorded on the dentin surface after sanding with abrasive paper $(\mathbf{a}, \mathbf{b}, \mathbf{c})$, after treatment with a $1 \%$ EDTA solution $(\mathbf{d}, \mathbf{e}, \mathbf{f})$, and after immersion in simulated body fluid (SBF) for $24 \mathrm{~h}(\mathbf{g}, \mathbf{h}, \mathbf{i})$ and two months $(\mathbf{l}, \mathbf{m}, \mathbf{n})$.
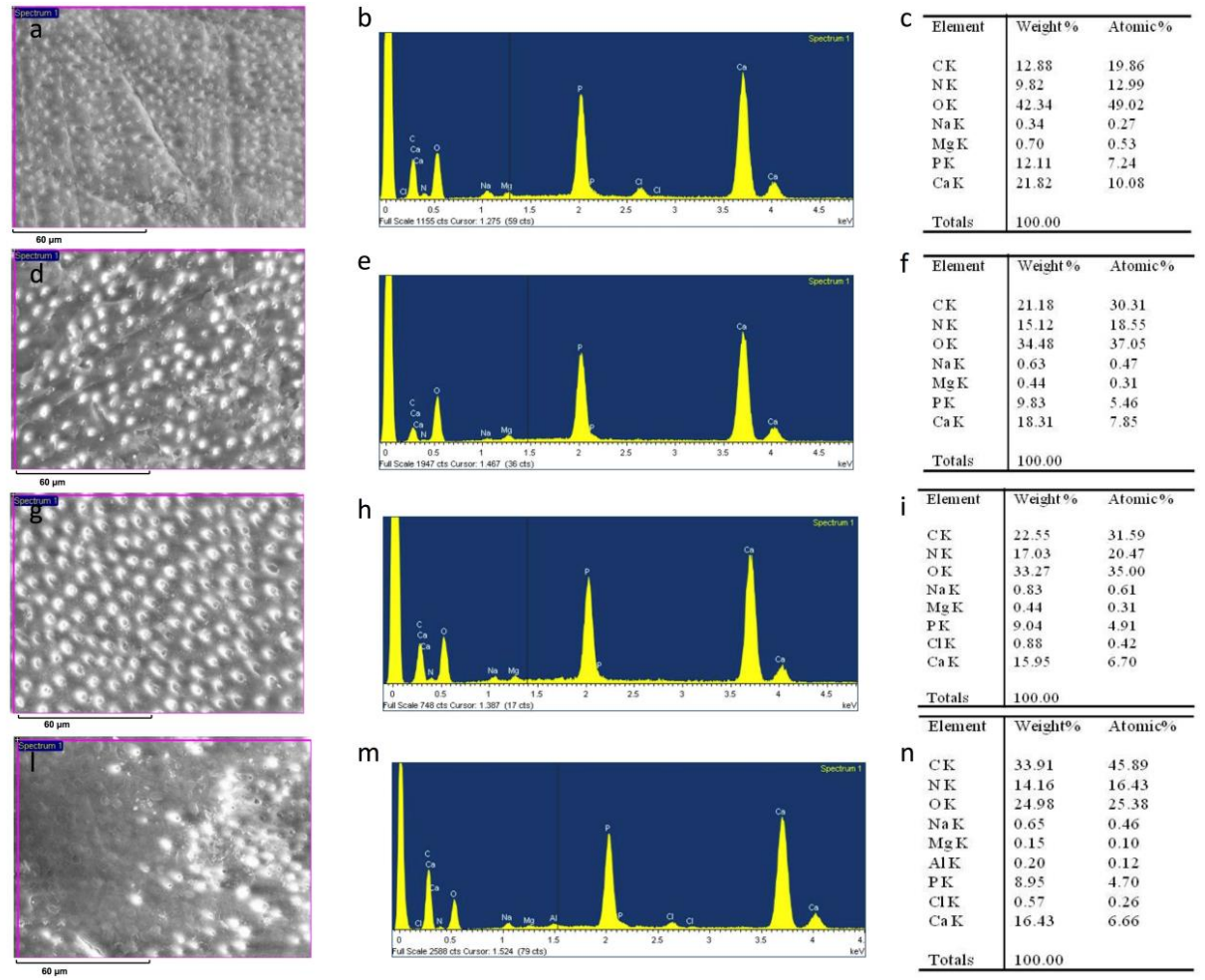

Figure 2. ESEM image, EDX spectra, and table of elements recorded on the dentin surface after sanding with abrasive paper $(\mathbf{a}, \mathbf{b}, \mathbf{c})$, after treatment with a 10\% EDTA (Tubuliclean 10\%) (d,e,f), and after immersion in SBF for $24 \mathrm{~h}(\mathbf{g}, \mathbf{h}, \mathbf{i})$ and two months $(\mathbf{l}, \mathbf{m}, \mathbf{n})$. 

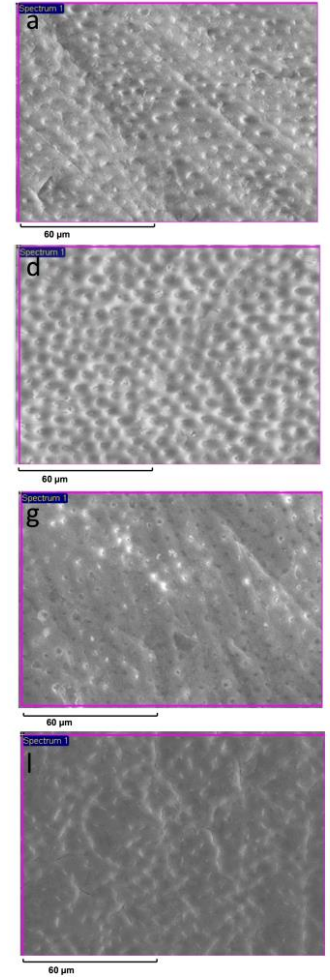

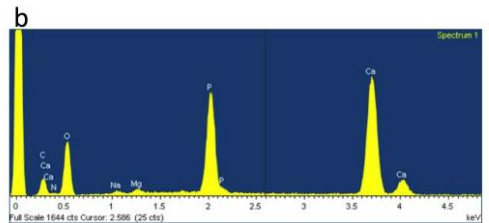

e

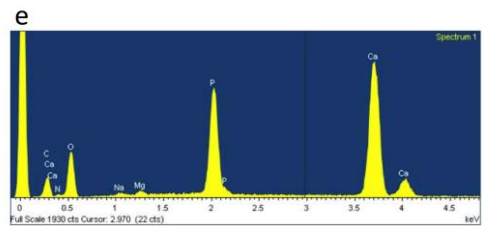

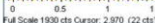
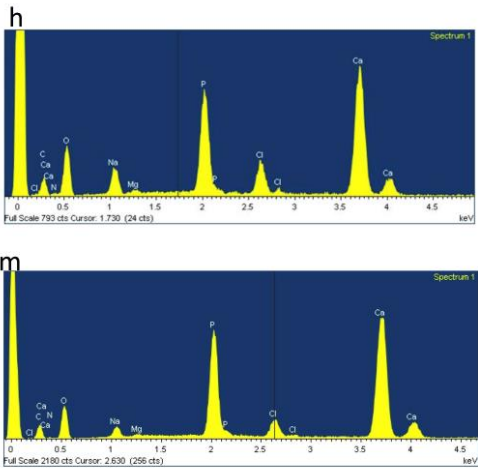

\begin{tabular}{c|ll}
\hline Clement & Weight \% & Atomic\% \\
$\mathrm{CK}$ & 12.57 & 19.32 \\
$\mathrm{NK}$ & 9.36 & 12.34 \\
$\mathrm{OK}$ & 43.85 & 50.59 \\
$\mathrm{NaK}$ & 0.57 & 0.46 \\
$\mathrm{Mg} \mathrm{K}$ & 0.51 & 0.39 \\
$\mathrm{PK}$ & 12.20 & 7.27 \\
$\mathrm{CaK}$ & 20.94 & 9.64 \\
$\mathrm{~T}$ & & \\
\hline
\end{tabular}

\begin{tabular}{|c|c|c|}
\hline Element & Weight $\%$ & Atomic\% \\
\hline $\mathrm{CK}$ & 14.60 & 22.54 \\
\hline NK & 10.73 & 14.20 \\
\hline $\mathrm{OK}$ & 38.46 & 44.57 \\
\hline Na K & 0.41 & 0.33 \\
\hline $\mathrm{Mg} \mathrm{K}$ & 0.47 & 0.36 \\
\hline $\mathrm{PK}$ & 12.21 & 7.31 \\
\hline $\mathrm{CaK}$ & 23.11 & 10.69 \\
\hline Totals & 100.00 & \\
\hline ¡ Element & Weight $\%$ & Atomic $\%$ \\
\hline $\mathrm{CK}$ & 15.22 & 23. \\
\hline N K & 10 & 14.45 \\
\hline or & 36.18 & 41.71 \\
\hline Na K & 4.05 & 3.25 \\
\hline $\operatorname{Mg} \mathrm{K}$ & 0.4 & 0.31 \\
\hline PK & 10.44 & 6.21 \\
\hline $\mathrm{ClK}$ & 38 & 1.9 \\
\hline $\mathrm{CaK}$ & 18.91 & 8.70 \\
\hline Totals & 100.00 & \\
\hline $\mathrm{n}$ Element & Weight $\%$ & Atomic\% \\
\hline $\mathrm{c} \mathrm{K}$ & 10.43 & 17 \\
\hline & & \\
\hline ok & 37. & 48.19 \\
\hline $\mathrm{NaK}$ & 0.7 & 0.6 \\
\hline $\mathrm{Mg} \mathrm{K}$ & 0.7 & 0.64 \\
\hline $\begin{array}{l}P K \\
P K\end{array}$ & 16.19 & 10.64 \\
\hline $\begin{array}{l}\mathrm{C} 1 \mathrm{~K} \\
\mathrm{CaK}\end{array}$ & $\mid \begin{array}{l}0.71 \\
28.09\end{array}$ & $\begin{array}{l}0.41 \\
14.26\end{array}$ \\
\hline Totals & 100.00 & \\
\hline
\end{tabular}

Figure 3. ESEM image, EDX spectra, and table of elements recorded on the dentin surface after sanding with abrasive paper $(\mathbf{a}, \mathbf{b}, \mathbf{c})$, after treatment with a 17\% EDTA (Germ EDTA 17\%) (d,e,f), and after immersion in SBF for $24 \mathrm{~h}(\mathbf{g}, \mathbf{h}, \mathbf{i})$ and two months $(\mathbf{l}, \mathbf{m}, \mathbf{n})$.
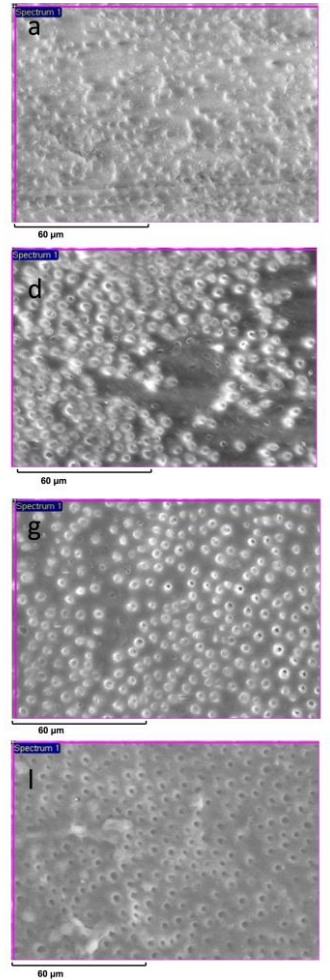
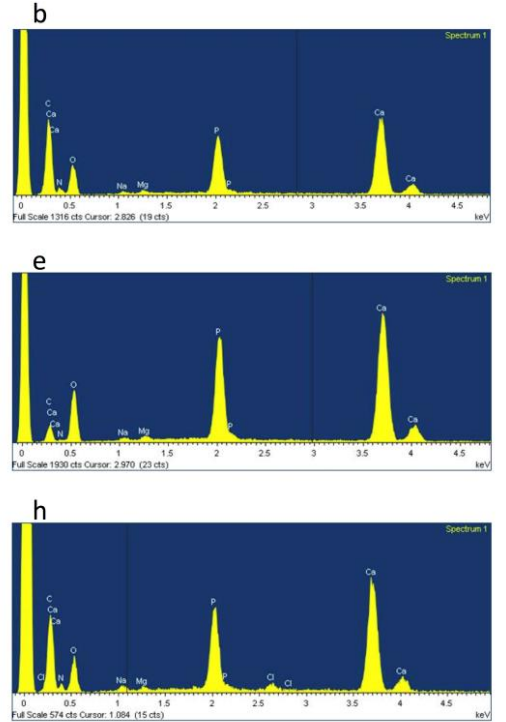

$\mathrm{m}$

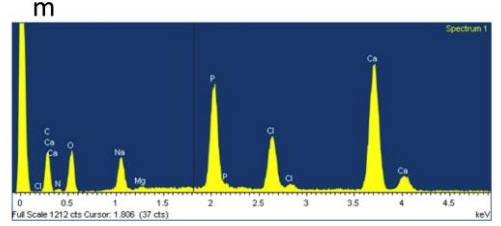

C
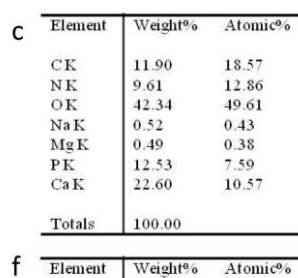

\begin{tabular}{l|ll}
$\mathrm{f}$ & & \\
\hline Element & Weight\% & Atomic\% \\
$\mathrm{CK}$ & 32.51 & 41.76 \\
$\mathrm{~N} \mathrm{~K}$ & 22.65 & 24.95 \\
$\mathrm{OK}$ & 26.20 & 25.26 \\
$\mathrm{NaK}$ & 0.36 & 0.24 \\
$\mathrm{MgK}$ & 0.29 & 0.18 \\
$\mathrm{P} \mathrm{K}$ & 6.02 & 3.00 \\
$\mathrm{Ca} \mathrm{K}$ & 11.98 & 4.61 \\
& & \\
Totals & 100.00 & \\
\hline
\end{tabular}

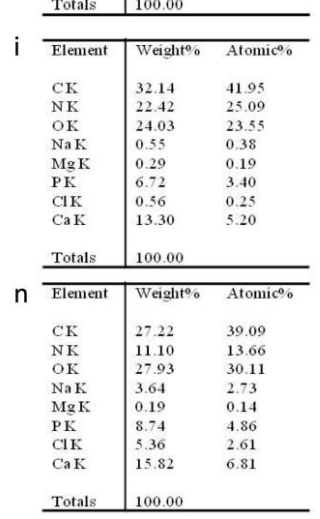

Figure 4. ESEM image, EDX spectra, and table of elements recorded on the dentin surface after sanding with abrasive paper $(\mathbf{a}, \mathbf{b}, \mathbf{c})$, after treatment with a $10 \%$ citric acid solution $(\mathbf{d}, \mathbf{e}, \mathbf{f})$, and after immersion in SBF for $24 \mathrm{~h}(\mathbf{g}, \mathbf{h}, \mathbf{i})$ and two months $(\mathbf{l}, \mathbf{m}, \mathbf{n})$. 

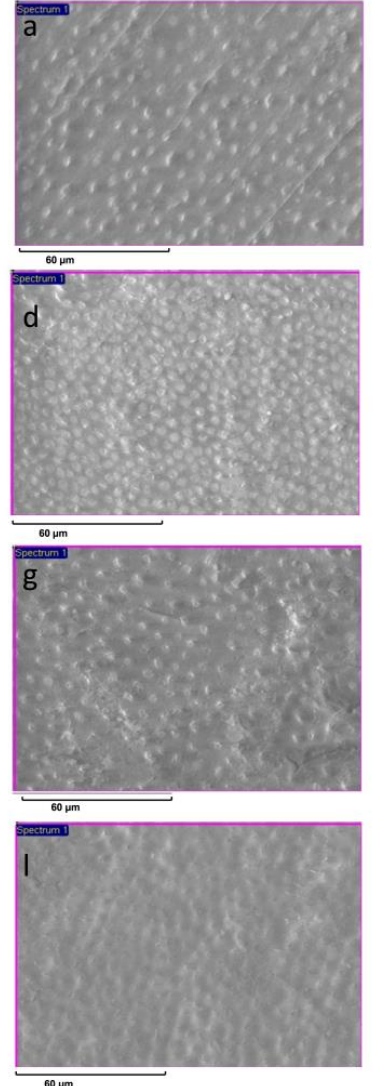
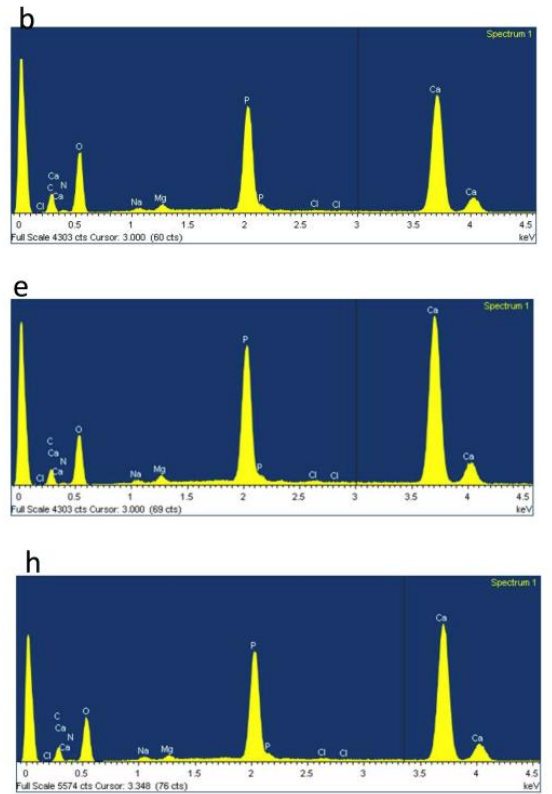

$\mathrm{m}$

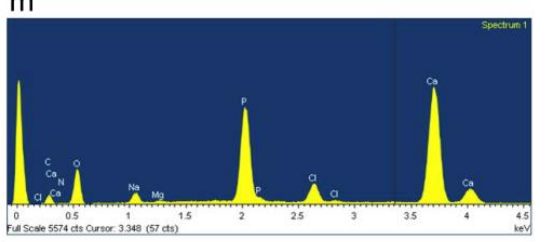

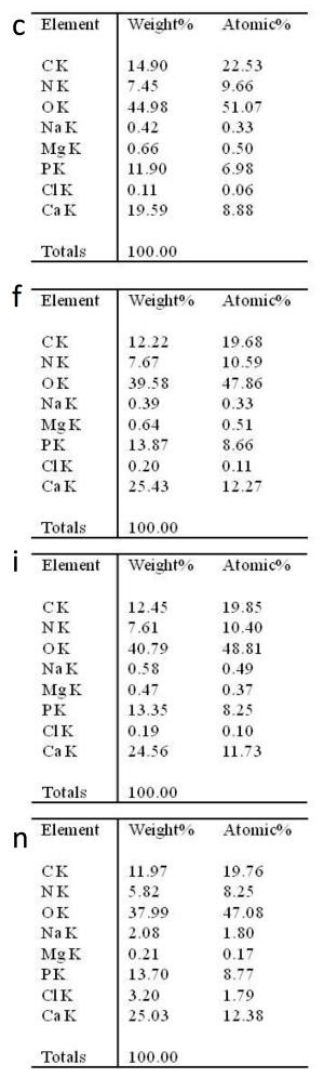

Figure 5. ESEM image, EDX spectra, and table of elements recorded on the dentin surface after sanding with abrasive paper $(\mathbf{a}, \mathbf{b}, \mathbf{c})$, after washing with distilled water $(\mathbf{d}, \mathbf{e}, \mathbf{f})$, and after immersion in SBF for $24 \mathrm{~h}(\mathbf{g}, \mathbf{h}, \mathbf{i})$ and two months $(\mathbf{l}, \mathbf{m}, \mathbf{n})$.

Table 2. Ca/N atomic ratios (mean \pm standard deviation (SD)). In columns, identical superscript lowercase letters represent no statistical differences (two-way analysis of variance (ANOVA) followed by an RM Student-Newman-Keuls test) among tested solutions $(P \geq 0.05)$. In the horizontal rows, identical superscript uppercase letters represent no statistical differences (one-way ANOVA for repeated measures followed by an RM Student-Newman-Keuls test) among evaluation times $(P \geq 0.05)$.

\begin{tabular}{ccccc}
\hline Treatments & Smear Layer & T0 & 24 Hours & 2 Months \\
\hline $1 \%$ EDTA & $0.84 \pm 0.06^{\mathrm{Aa}}$ & $0.59 \pm 0.05^{\mathrm{Aa}}$ & $0.67 \pm 0.14^{\mathrm{Aa}}$ & $2.34 \pm 0.51^{\mathrm{Ba}}$ \\
$10 \%$ EDTA & $0.85 \pm 0.09^{\mathrm{Aa}}$ & $0.40 \pm 0.03^{\mathrm{Ba}}$ & $0.31 \pm 0.03^{\mathrm{Bb}}$ & $0.91 \pm 0.49^{\mathrm{Ab}}$ \\
$17 \%$ EDTA & $0.72 \pm 0.05^{\mathrm{Ab}}$ & $0.70 \pm 0.04^{\mathrm{Ab}}$ & $0.66 \pm 0.06^{\mathrm{Aa}}$ & $1.56 \pm 0.39^{\mathrm{Bc}}$ \\
$10 \%$ Citric acid & $1.09 \pm 0.06^{\mathrm{Ac}}$ & $0.26 \pm 0.02^{\mathrm{Bc}}$ & $0.31 \pm 0.03^{\mathrm{Bb}}$ & $0.33 \pm 0.01^{\mathrm{Bd}}$ \\
Control & $0.83 \pm 0.08^{\mathrm{Aa}}$ & $1.17 \pm 0.04^{\mathrm{Bd}}$ & $1.12 \pm 0.08^{\mathrm{Bc}}$ & $1.45 \pm 0.19^{\mathrm{Bc}}$ \\
\hline
\end{tabular}

Table 3. $\mathrm{P} / \mathrm{N}$ atomic ratios (mean $\pm \mathrm{SD}$ ). In columns, identical superscript lowercase letters represent no statistical differences (two-way ANOVA followed by an RM Student-Newman-Keuls test) among tested solutions $(P \geq 0.05)$. In the horizontal rows, identical superscript uppercase letters represent no statistical differences (one-way ANOVA for repeated measures followed by an RM Student-Newman-Keuls test) among evaluation times $(P \geq 0.05)$.

\begin{tabular}{ccccc}
\hline Treatments & Smear Layer & T0 & 24 Hours & 2 Months \\
\hline $1 \%$ EDTA & $0.62 \pm 0.05^{\mathrm{Aa}}$ & $0.41 \pm 0.02^{\mathrm{Aa}}$ & $0.48 \pm 0.10^{\mathrm{Aa}}$ & $1.80 \pm 0.46^{\mathrm{Ba}}$ \\
$10 \%$ EDTA & $0.61 \pm 0.07^{\mathrm{Aa}}$ & $0.29 \pm 0.02^{\mathrm{Ba}}$ & $0.23 \pm 0.03^{\mathrm{Ba}}$ & $0.65 \pm 0.35^{\mathrm{Ab}}$ \\
$17 \%$ EDTA & $0.53 \pm 0.06^{\mathrm{Aa}}$ & $0.48 \pm 0.03^{\mathrm{Aa}}$ & $0.47 \pm 0.04^{\mathrm{Aa}}$ & $1.11 \pm 0.27^{\mathrm{Bc}}$ \\
$10 \%$ Citric acid & $0.79 \pm 0.03^{\mathrm{Aa}}$ & $0.19 \pm 0.01^{\mathrm{Ba}}$ & $0.22 \pm 0.02^{\mathrm{Ba}}$ & $0.22 \pm 0.01^{\mathrm{Bd}}$ \\
Control & $0.65 \pm 0.06^{\mathrm{Aa}}$ & $0.82 \pm 0.03^{\mathrm{Bb}}$ & $0.78 \pm 0.06^{\mathrm{Bb}}$ & $1.04 \pm 0.14^{\mathrm{Bc}}$ \\
\hline
\end{tabular}


Table 4. $\mathrm{Ca} / \mathrm{P}$ atomic ratios (mean $\pm \mathrm{SD}$ ). In columns, identical superscript lowercase letters represent no statistical differences (two-way ANOVA followed by an RM Student-Newman-Keuls test) among tested solutions $(P \geq 0.05)$. In the horizontal rows, identical superscript uppercase letters represent no statistical differences (one-way ANOVA for repeated measures followed by an RM Student-Newman-Keuls test) among evaluation times $(P \geq 0.05)$.

\begin{tabular}{ccccc}
\hline Treatments & Smear Layer & T0 & 24 Hours & 2 Months \\
\hline $1 \%$ EDTA & $1.35 \pm 0.01^{\mathrm{Aa}}$ & $1.43 \pm 0.06^{\mathrm{Ba}}$ & $1.41 \pm 0.02^{\mathrm{Ba}}$ & $1.31 \pm 0.04^{\mathrm{Aa}}$ \\
$10 \%$ EDTA & $1.38 \pm 0.01^{\mathrm{Aa}}$ & $1.41 \pm 0.04^{\mathrm{Aa}}$ & $1.36 \pm 0.01^{\mathrm{Bb}}$ & $1.41 \pm 0.01^{\mathrm{Ab}}$ \\
$17 \%$ EDTA & $1.32 \pm 0.02^{\mathrm{Ab}}$ & $1.47 \pm 0.01^{\mathrm{Bb}}$ & $1.40 \pm 0.02^{\mathrm{Ca}}$ & $1.40 \pm 0.03^{\mathrm{Cb}}$ \\
$10 \%$ Citric acid & $1.38 \pm 0.03^{\mathrm{Aa}}$ & $1.33 \pm 0.01^{\mathrm{Bc}}$ & $1.43 \pm 0.02^{\mathrm{Ca}}$ & $1.45 \pm 0.02^{\mathrm{Cc}}$ \\
Control & $1.27 \pm 0.01^{\mathrm{Ac}}$ & $1.42 \pm 0.00^{\mathrm{Ba}}$ & $1.43 \pm 0.01^{\mathrm{Ba}}$ & $1.40 \pm 0.01^{\mathrm{Bb}}$ \\
\hline
\end{tabular}
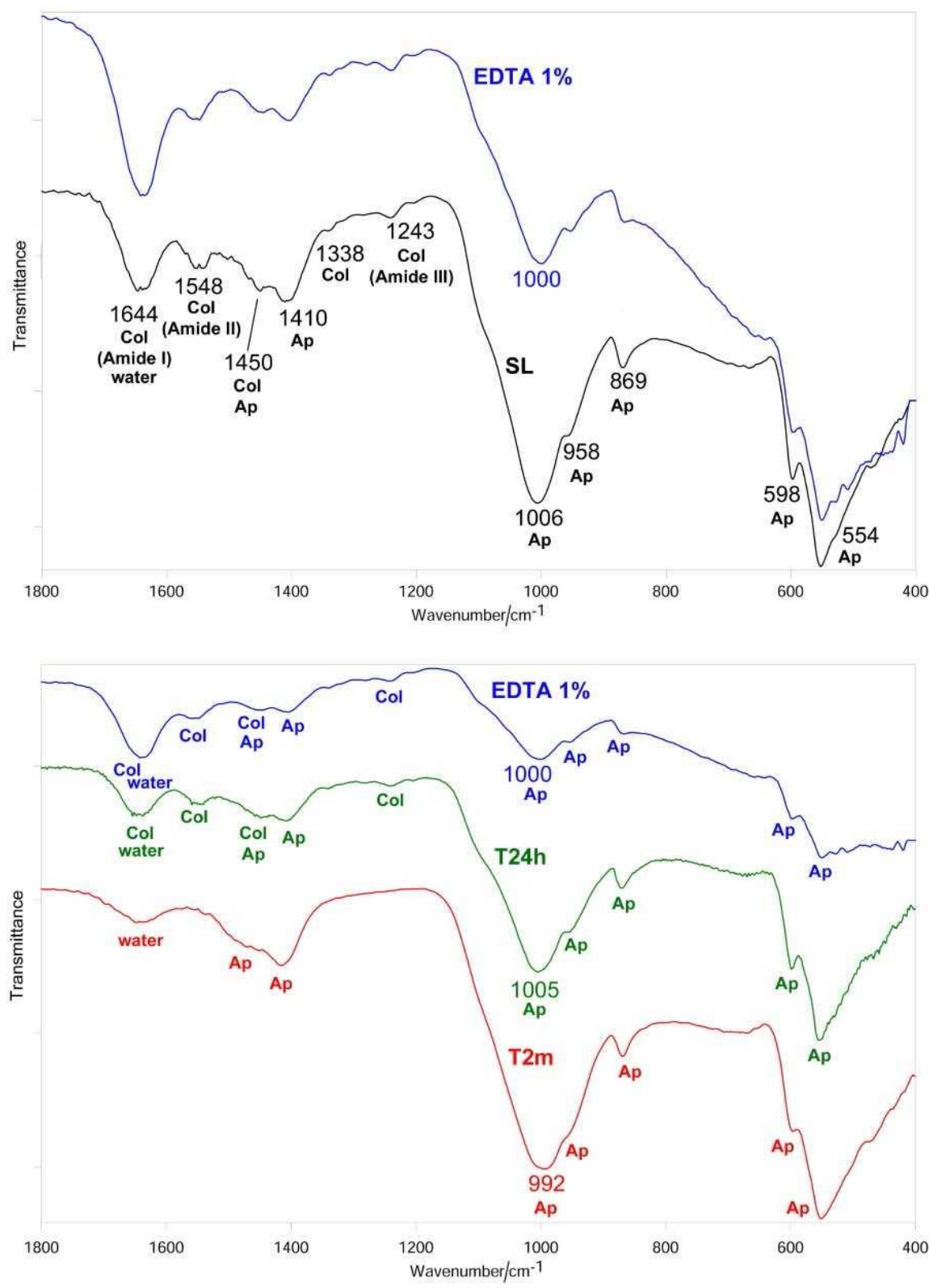

Figure 6. Average IR spectra recorded on the dentin surface after sanding (smear layer (SL), black), treatment with 1\% EDTA (blue), aging in SBF for $24 \mathrm{~h}$ (T24h, green) and two months (T2m, red). The bands prevalently assignable to collagen (Col), water, and B-type carbonated apatite (Ap) are indicated. 

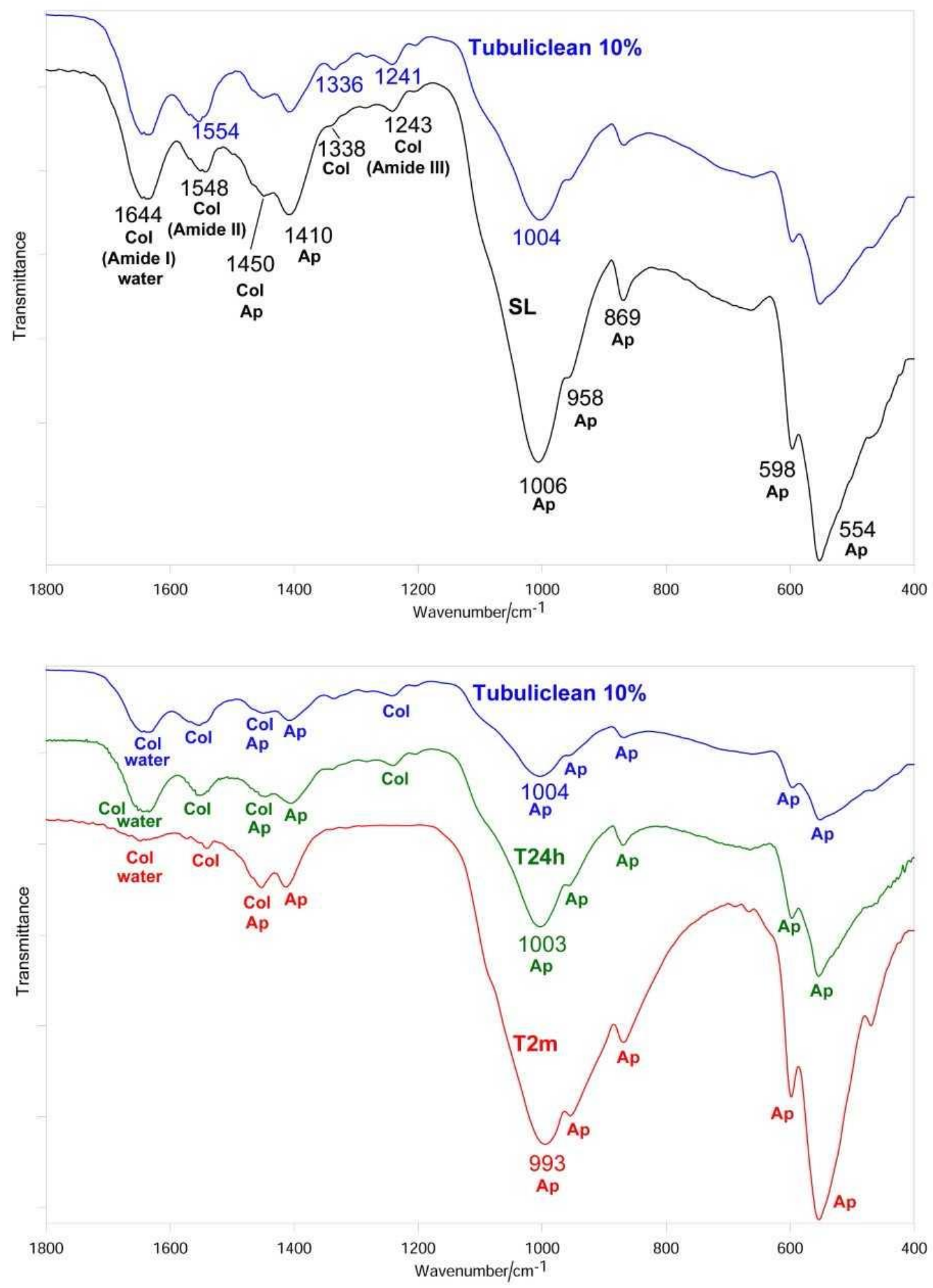

Figure 7. Average IR spectra recorded on the dentin surface after sanding (SL, black), treatment with 10\% EDTA (Tubuliclean 10\%) (blue), aging in SBF for $24 \mathrm{~h}$ (T24h, green) and two months (T2m, red). The bands prevalently assignable to collagen (Col), water, and B-type carbonated apatite (Ap) are indicated. 

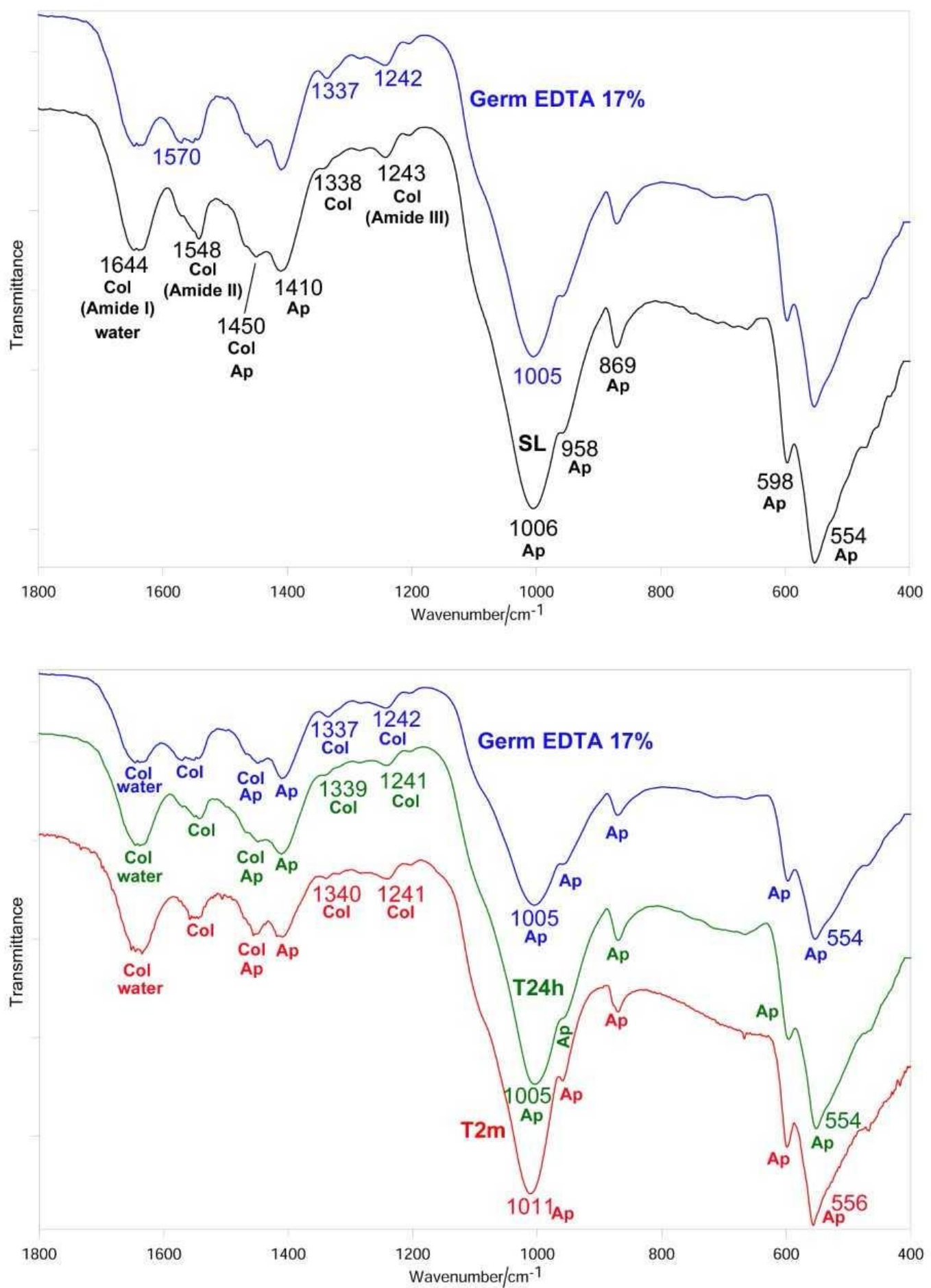

Figure 8. Average IR spectra recorded on the dentin surface after sanding (SL, black), treatment with 17\% EDTA (Germ EDTA 17\%) (blue), aging in SBF for $24 \mathrm{~h}$ (T24h, green) and two months (T2m, red). The bands prevalently assignable to collagen ( $\mathrm{Col})$, water, and B-type carbonated apatite (Ap) are indicated. 

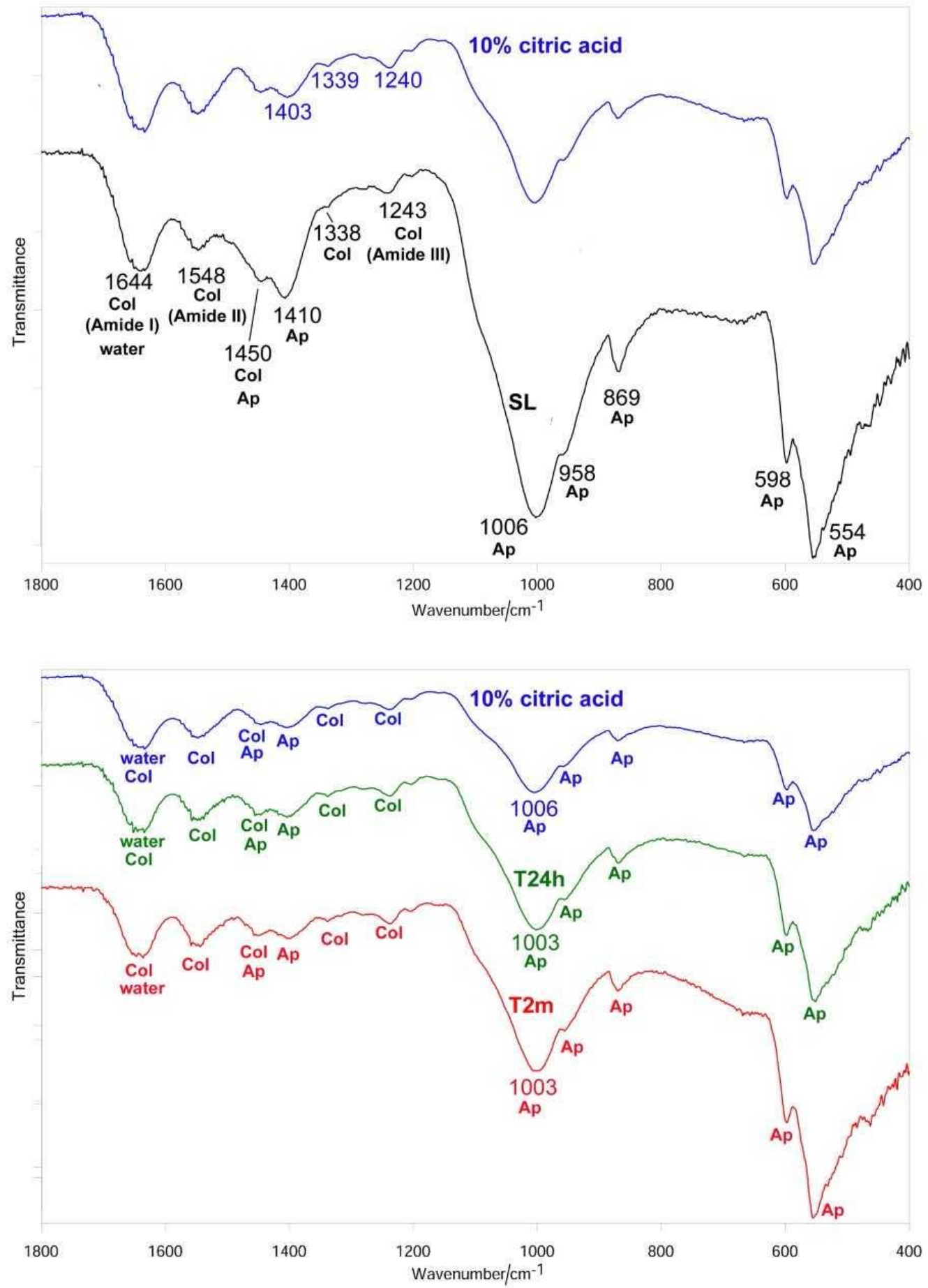

Figure 9. Average IR spectra recorded on the dentin surface after sanding (SL, black), treatment with $10 \%$ citric acid solution (blue), aging in SBF for $24 \mathrm{~h}$ (T24h, green) and two months (T2m, red). The bands prevalently assignable to collagen $(\mathrm{Col})$, water, and B-type carbonated apatite (Ap) are indicated. 


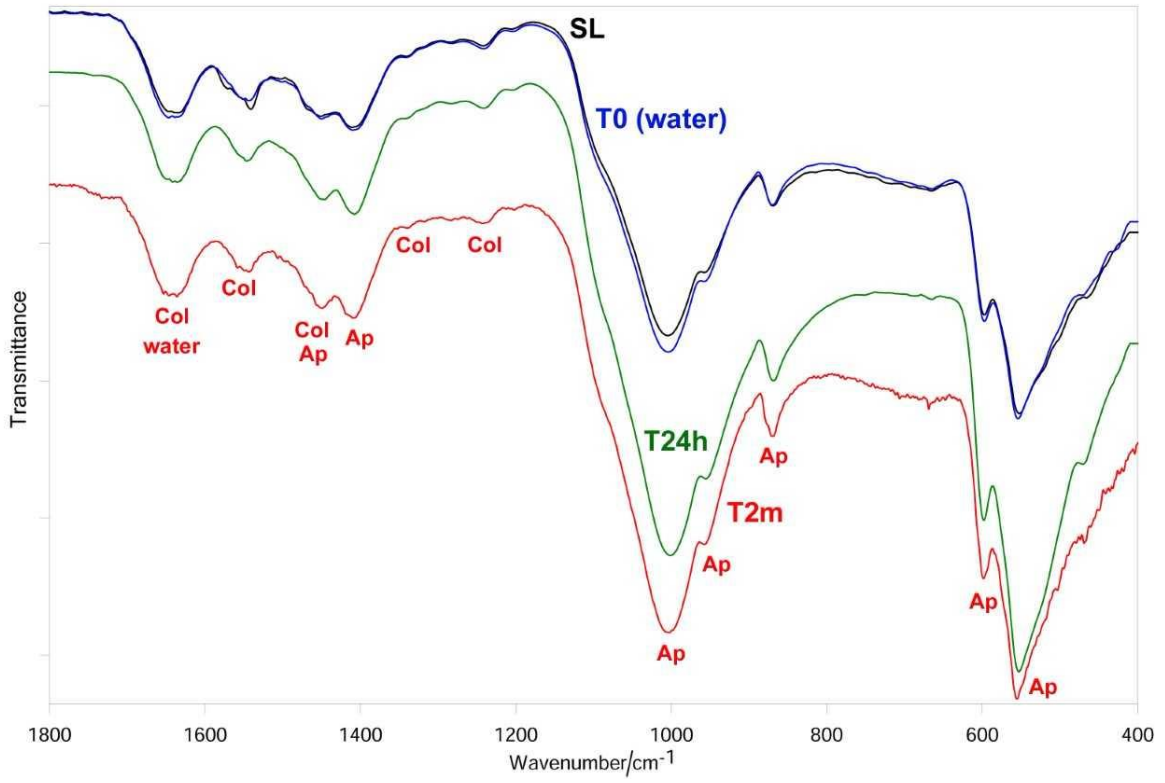

Figure 10. Average IR spectra recorded on the control dentin surface after sanding (SL, black), treatment with water (blue), aging in SBF for $24 \mathrm{~h}$ (T24h, green) and two months (T2m, red). The bands prevalently assignable to collagen $(\mathrm{Col})$, water, and B-type carbonated apatite (Ap) are indicated.
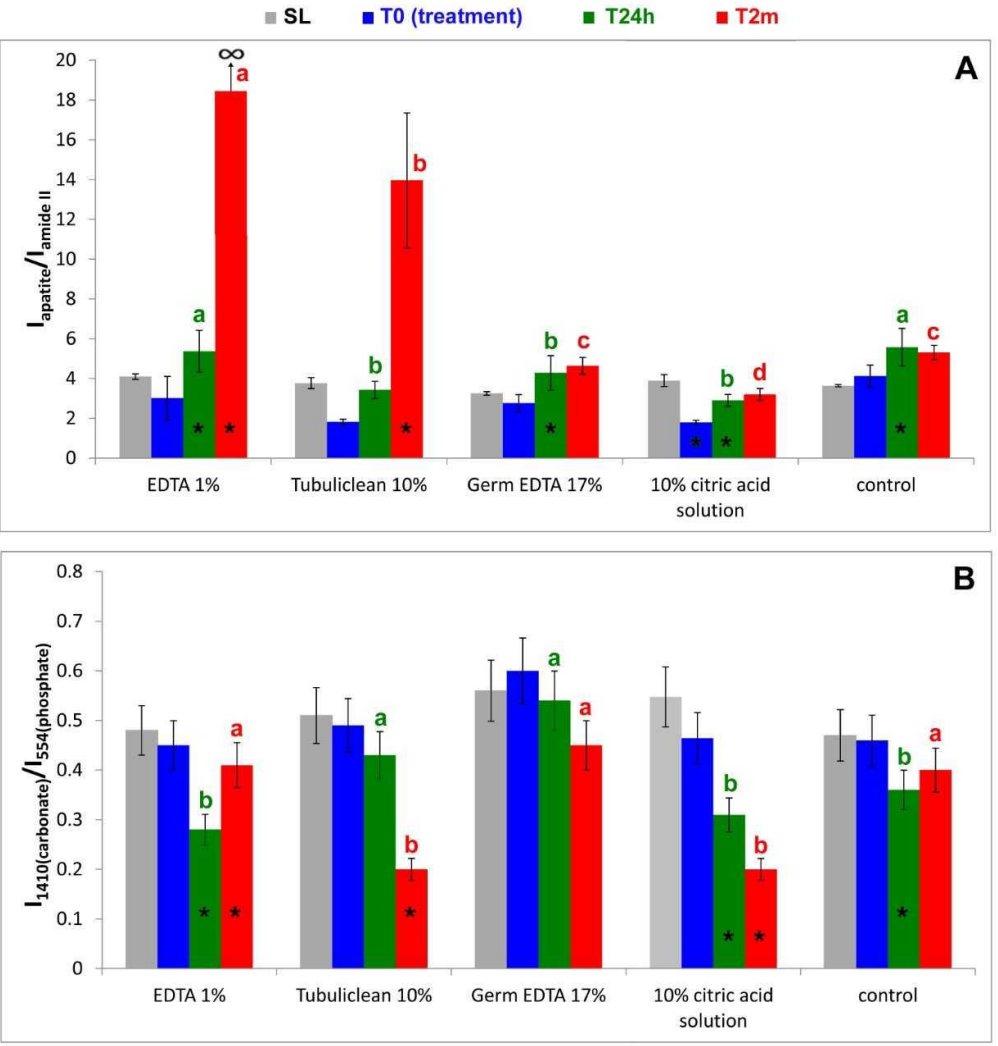

Figure 11. Values of the Iapatite/Iamide II (A) and I1410(carbonate)/I554(phosphate) (B) ratios (average \pm standard deviation), as calculated from the IR spectra recorded on the dentin surfaces under study, submitted to sanding (SL, grey), treatment with 1\% EDTA, 10\% EDTA (Tubuliclean 10\%), 17\% EDTA (Germ EDTA 17\%), 10\% citric acid solution, or water (blue), aging in SBF for $24 \mathrm{~h}$ (T24h, green) and two months (T2m, red). The asterisks on the histogram bars indicated significant differences with respect to the value observed in the previous step of the study within the same treatment. Identical letters represent no statistical differences $(P \geq 0.05)$ among tested solutions at $\mathrm{T} 24 \mathrm{~h}$ or $\mathrm{T} 2 \mathrm{~m}$. 


\section{1. $1 \%$ EDTA}

After treatment with the chelating agent, ESEM showed that the dentinal tubules were completely open; smear plugs were absent, resulting in dentinal tubules that were completely free from debris, see Figure 1d. EDX showed high peaks of $\mathrm{Ca}$ and $\mathrm{P}$, with similar intensities to those after sanding with abrasive paper; conversely, the $\mathrm{O}$ peak was weaker, while the signals from $\mathrm{N}$ and $\mathrm{C}$ were stronger, due to their increased contribution to dentine composition following demineralization, see Figure 1e.

The occurrence of this process was confirmed by the decrease of the $\mathrm{Ca} / \mathrm{N}$ and $\mathrm{P} / \mathrm{N}$ ratios upon the treatment; the former decreased from $0.84 \pm 0.06$ to $0.59 \pm 0.05$, see Figure $1 \mathrm{f}$ and Table 2, the latter from $0.62 \pm 0.05$ to $0.41 \pm 0.02$, see Figure $1 \mathrm{f}$ and Table 3 . However, these changes were not statistically significant $(P>0.05)$. The $\mathrm{Ca} / \mathrm{P}$ ratio significantly increased from $1.35 \pm 0.01$ to $1.43 \pm$ 0.06 , see Figure $1 \mathrm{f}$ and Table 4.

IR spectroscopy confirmed the occurrence of demineralization; in fact, the bands assigned to B-type carbonated apatite decreased in intensity with respect to those of collagen, without disappearing, see Figure 6. The Amide bands did not undergo any shift upon treatment; on the contrary, the $v_{3}$ $\mathrm{PO}_{4}{ }^{3-}$ band shifted from 1006 to $1000 \mathrm{~cm}^{-1}$. Wavenumber positions of the main IR bands of collagen and apatite are reported in Table 5.

Table 5. IR band wavenumber positions $\left(\mathrm{cm}^{-1}\right)$.

\begin{tabular}{ccccc}
\hline Treatments-Time & Collagen Amide II & $\begin{array}{c}\text { Collagen COO } \\
\text { Stretching Band }\end{array}$ & $\begin{array}{c}\text { Collagen } \\
\text { Amide III }\end{array}$ & $\begin{array}{c}\text { Apatite, } \mathbf{v}_{\mathbf{3}} \mathbf{P O}_{\mathbf{4}} \mathbf{3}^{-} \\
\text {Stretching }\end{array}$ \\
\hline Smear layer & 1548 & 1338 & 1243 & 1006 \\
$1 \%$ EDTA-T0 & 1548 & 1338 & 1243 & 1000 \\
24 hours & 1548 & 1338 & 1243 & 1005 \\
2 months & not detected & not detected & not detected & 992 \\
$10 \%$ EDTA-T0 & 1554 & 1336 & 1241 & 1004 \\
24 hours & 1554 & 1336 & 1241 & 1003 \\
2 months & very weak & not detected & not detected & 993 \\
$17 \%$ EDTA-T0 & $1570-1548$ & 1337 & 1242 & 1005 \\
24 hours & 1548 & 1339 & 1241 & 1005 \\
2 months & 1548 & 1340 & 1241 & 1011 \\
$10 \%$ citric acid-T0 & 1548 & 1339 & 1240 & 1006 \\
24 hours & 1548 & 1339 & 1240 & 1003 \\
2 months & 1548 & 1339 & 1240 & 1003 \\
control-T0 & 1548 & 1338 & 1243 & 1006 \\
24 hours & 1548 & 1338 & 1243 & 1006 \\
2 months & 1548 & 1338 & 1243 & 1006 \\
\hline
\end{tabular}

The $I_{\text {apatite }} / I_{\text {amide II }}$ ratio decreased upon treatment with $1 \%$ EDTA, see Figure $11 \mathrm{~A}$, although its change was not significant $(P>0.05)$, in agreement with the EDX data. No significant variations in the $I_{1410 \text { (carbonate) }} / I_{554 \text { (phosphate) }}$ ratio were observed, see Figure 11B.

After immersion in SBF for $24 \mathrm{~h}$, ESEM showed open dentinal tubules and small precipitates that are not able to occlude all the tubules, see Figure $1 \mathrm{~g}$.

EDX showed peaks of $\mathrm{Ca}$ and $\mathrm{P}$ similar to those after sanding and after treatment at T0. N and $\mathrm{C}$ levels were similar to those immediately after treatment. The chlorine $(\mathrm{Cl})$ peak appeared upon immersion in SBF, see Figure $1 \mathrm{~h}$. Both the $\mathrm{Ca} / \mathrm{N}$ and $\mathrm{P} / \mathrm{N}$ ratios increased slightly, see Figure $1 \mathrm{i}$ and Tables 2 and 3, but not significantly, suggesting only a small remineralization. The $\mathrm{Ca} / \mathrm{P}$ ratio remained unchanged, see Figure 1i and Table 4. After aging in SBF for two months, ESEM showed several precipitates on the surface, see Figure 11.

EDX showed high peaks of $\mathrm{Ca}, \mathrm{P}$, and $\mathrm{O}$; high levels of $\mathrm{N}$ and $\mathrm{C}$ were also registered together with some $\mathrm{Cl}$, see Figure $1 \mathrm{~m}$. The $\mathrm{Ca} / \mathrm{N}$ and $\mathrm{P} / \mathrm{N}$ ratios underwent significant increases, suggesting the occurrence of a marked degree of remineralization; at the same time, the $\mathrm{Ca} / \mathrm{P}$ ratio resembled that observed after sanding, see Figure $1 \mathrm{n}$ and Tables 2-4. 
IR spectroscopy confirmed the progressive remineralization observed by ESEM/EDX. Upon aging in SBF for $24 \mathrm{~h}$, see Figure 6, the apatite bands were found to strengthen with respect to those assignable to collagen and the $I_{\text {apatite }} / I_{\text {amide II }}$ ratio significantly increased, see Figure $11 \mathrm{~A}$; after two months, the collagen amide II and III bands became undetectable, so that $I_{\text {apatite }} / I_{\text {amide II }} \rightarrow \infty$, see Figure 11A. At $24 \mathrm{~h}$ of aging, the $v_{3} \mathrm{PO}_{4}{ }^{3-}$ band shifted to $1005 \mathrm{~cm}^{-1}$, i.e., to a wavenumber value similar to that observed upon sanding; a further shift to lower wavenumber values was observed after two months, see Table 5. With respect to the SL sample, the $v_{3} \mathrm{PO}_{4}{ }^{3-}$ band fell at a lower wavenumber value and was visibly broadened, see Figure 6.

At $24 \mathrm{~h}$ of aging, the $I_{1410 \text { (carbonate) }} / I_{554 \text { (phosphate) }}$ ratio (and thus carbonate content) was lower than in the SL sample, see Figure 11B; after two months, it increased attaining nearly the same value observed in the SL sample.

\section{2. $10 \%$ EDTA}

After treatment with the chelating agent, ESEM showed that the dentinal tubules were completely open and completely free from debris with some precipitates present on the surface, see Figure $2 \mathrm{~d}$. EDX still showed peaks of $\mathrm{Ca}, \mathrm{P}$, and $\mathrm{O}$ but with lower values than before. Conversely, as previously observed for the treatment with the 1\% EDTA solution, $\mathrm{N}$ and $\mathrm{C}$ values were higher than before, see Figure 2e. The $\mathrm{Ca} / \mathrm{P}$ ratio remained unchanged, see Figure $2 \mathrm{f}$ and Table 4 . Both the $\mathrm{Ca} / \mathrm{N}$ and $\mathrm{P} / \mathrm{N}$ ratios decreased, see Figure $2 \mathrm{f}$ and Tables 2 and 3 , but only the change of the latter parameter appeared significant (from $0.61 \pm 0.07$ to $0.29 \pm 0.02$ ), suggesting the occurrence of a marked demineralization after the treatment.

IR spectroscopy confirmed this behavior, showing the already observed decrease in the relative intensity of the apatite bands, see Figure 7 , and thus, in the $I_{\text {apatite }} / I_{\text {amide II }}$ ratio, see Figure $11 \mathrm{~A}$. The treatment with 10\% EDTA induced a shift in the collagen Amide II and III bands, as well as in the $\mathrm{COO}^{-}$stretching band at about $1338 \mathrm{~cm}^{-1}$, see Table 5; the shift in the $v_{3} \mathrm{PO}_{4}{ }^{3-}$ band was lower than upon treatment with $1 \%$ EDTA, see Table 5 . No significant variations in the $I_{1410 \text { (carbonate) }} / I_{554 \text { (phosphate) }}$ ratio were observed, as shown in Figure 11B.

After immersion in SBF for $24 \mathrm{~h}$, ESEM showed few precipitates and all tubules were clearly open, see Figure 2g. EDX showed peaks that were very similar to those at T0, as shown in Figure $2 \mathrm{~h}$; the Ca/N, $\mathrm{P} / \mathrm{N}$ and $\mathrm{Ca} / \mathrm{P}$ ratios remained unchanged compared with $\mathrm{T} 0$, see Figure $2 \mathrm{i}$ and Tables $2-4$, suggesting that the treatment with $10 \%$ EDTA had prevented remineralization at this stage. After immersion in SBF for two months, ESEM showed some dentinal tubules were still open, as shown in Figure 21.

EDX showed intense peaks of $\mathrm{Ca}, \mathrm{P}$, and $\mathrm{O} ; \mathrm{N}$ and $\mathrm{C}$ levels were also high, see Figure $2 \mathrm{~m}$. The $\mathrm{Ca} / \mathrm{N}$ and $\mathrm{P} / \mathrm{N}$ ratios appeared increased at this stage, although the high standard deviation associated with the measurements meant the changes were not statistically significant, see Figure $2 \mathrm{n}$ and Tables $2-4$. These trends showed that at this stage remineralization occurred.

The IR spectra confirmed these trends, see Figure 7 . After $24 \mathrm{~h}$ of aging the $I_{\text {apatite }} / I_{\text {amide II }}$ ratio increased, but not significantly, while at two months the increase became significant, see Figure $11 \mathrm{~A}$; at this stage, the amide III band became undetectable, while the amide I and II bands were observed as weak spectral features, see Figure 7. With respect to the sanded sample, the $v_{3} \mathrm{PO}_{4}{ }^{3-}$ band shifted to lower wavenumber value and broadened, see Figure 7 and Table 5. No significant variations in the $I_{1410 \text { (carbonate) }} / I_{554 \text { (phosphate) }}$ ratio were observed at $24 \mathrm{~h}$, while after two months a significant decrease in the carbonate content of the B-type carbonated apatite was observed, as shown in Figure 11B.

\section{3. $17 \%$ EDTA}

After treatment with the chelating agent, ESEM showed that most of the dentinal tubules were completely open; smear plugs were absent. Peritubular dentine was compact and homogeneous, see Figure 3d. EDX showed the same peaks as before; the $\mathrm{O}$ level was a little lower, see Figure 3e. The $\mathrm{Ca} / \mathrm{N}$ and $\mathrm{P} / \mathrm{N}$ ratios remained practically unchanged upon treatment, while the $\mathrm{Ca} / \mathrm{P}$ ratio increased, as previously observed for 1\% EDTA, see Figure $3 \mathrm{f}$ and Tables 2-4. IR spectra showed 
only an insignificant reduction of the $I_{\text {apatite }} / I_{\text {amide II }}$ ratio, see Figure $11 \mathrm{~A}$, in agreement with the EDX results. The Amide II and III bands shifted upon treatment, as well as the $\mathrm{COO}^{-}$stretching mode and the $v_{3} \mathrm{PO}_{4}{ }^{3-}$ band, see Figure 8 and Table 5 . No significant variations in the $I_{1410 \text { (carbonate) }} / I_{554 \text { (phosphate) }}$ ratio were observed, see Figure $11 \mathrm{~B}$.

After immersion in SBF for $24 \mathrm{~h}$, ESEM showed open dentinal tubules and small precipitates that were not able to occlude all the tubules, see Figure 3g. EDX showed peaks and contents similar to those at T0, see Figure 3h, and no significant changes were observed in the $\mathrm{Ca} / \mathrm{N}$ and $\mathrm{P} / \mathrm{N}$ ratios, as shown in Figure $3 \mathbf{i}$ and Tables 2 and 3, while the Ca/P ratio decreased, see Figure $3 \mathbf{i}$ and Table 4. After immersion in SBF for two months, ESEM showed a few precipitates and some open tubules, see Figure 31.

EDX showed intense peaks of $\mathrm{Ca}, \mathrm{P}$, and $\mathrm{O}$ and high levels of $\mathrm{C}$, see Figure $3 \mathrm{~m}$. Additionally, $\mathrm{N}$ and $\mathrm{Cl}$ were registered. As observed for the treatment with Tubuliclean 10\%, at this stage, remineralization occurred, as indicated by the significant increases in the $\mathrm{Ca} / \mathrm{N}$ and $\mathrm{P} / \mathrm{N}$ ratios, see Figure $3 \mathrm{n}$ and Tables 2 and 3; the former increased from $0.66 \pm 0.06$ to $1.56 \pm 0.39$, the latter from $0.47 \pm 0.04$ to $1.11 \pm 0.27$.

IR spectra, see Figure 8, showed that after $24 \mathrm{~h}$ of aging, the relative intensity of the apatite bands and thus the $I_{\text {apatite }} / I_{\text {amide II }}$ ratio, shown in Figure 11A, significantly increased; no further increases were observed after two months. The Amide III, the COO${ }^{-}$stretching mode, and the $v_{3} \mathrm{PO}_{4}{ }^{3-}$ and $v_{4}$ $\mathrm{PO}_{4}{ }^{3-}$ bands underwent significant shifts in their wavenumber values, see Table 5 . It is interesting to note that the $v_{3} \mathrm{PO}_{4}{ }^{3-}$ mode shifted in an opposite manner with respect to the previous samples and sharpened rather than broadened. No significant variations in the $I_{1410 \text { (carbonate) }} / I_{554 \text { (phosphate) }}$ ratio were observed at $24 \mathrm{~h}$ and two months, see Figure 11B.

\subsection{Citric Acid Solution}

After treatment with the citric acid solution, ESEM showed that all dentinal tubules were completely open; smear plugs were absent, resulting in dentinal tubules that were completely free from debris. Peritubular dentine was compact and homogeneous, see Figure $4 \mathrm{~d}$.

EDX showed lower peaks of $\mathrm{Ca}, \mathrm{P}$, and $\mathrm{O}$ than before and higher levels of $\mathrm{N}$ and $\mathrm{C}$, see Figure $4 \mathrm{e}$. The $\mathrm{Ca} / \mathrm{N}$ and $\mathrm{P} / \mathrm{N}$ ratios significantly decreased upon treatment, suggesting the occurrence of a very strong demineralization, see Figure $4 \mathrm{f}$ and Tables 2 and 3; the former decreased from $1.09 \pm 0.06$ to $0.26 \pm 0.02$ and the latter from $0.79 \pm 0.03$ to $0.19 \pm 0.01$. The $\mathrm{Ca} / \mathrm{P}$ ratio decreased immediately after treatment and increased after $24 \mathrm{~h}$ and two months, see Figure $4 \mathrm{f}$ and Table 4 . IR spectroscopy, see Figure 9, confirmed this result: the $I_{\text {apatite }} / I_{\text {amide II }}$ ratio, see Figure $11 \mathrm{~A}$, significantly decreased from $3.9 \pm 0.3$ to $1.8 \pm 0.2$ and certain shifts in the collagen Amide III and $\mathrm{COO}^{-}$stretching bands were detected, see Table 5. No significant variations in the $I_{1410 \text { (carbonate) }} / I_{554 \text { (phosphate) }}$ ratio were observed, as shown in Figure 11B. After immersion in SBF for $24 \mathrm{~h}$, ESEM showed open dentinal tubules and precipitates were absent, see Figure $4 \mathrm{~g}$. EDX showed component levels that were similar to those at T0, see Figure $4 \mathrm{~h}$, and accordingly, the $\mathrm{Ca} / \mathrm{N}$ and $\mathrm{P} / \mathrm{N}$ ratios did not undergo any significant change, see Figure 4i and Tables 2-4. After immersion in SBF for two months, ESEM did not show precipitates and all dentinal tubules were clearly open, as shown in Figure 4l. EDX showed high peaks of $\mathrm{Ca}, \mathrm{P}, \mathrm{O}, \mathrm{N}$, and $\mathrm{C} ; \mathrm{Cl}$ was still present, see Figure $4 \mathrm{~m}$. The $\mathrm{Ca} / \mathrm{N}$ and $\mathrm{P} / \mathrm{N}$ ratios remained constant; the $\mathrm{Ca} / \mathrm{P}$ ratio decreased, see Figure $4 \mathrm{n}$ and Tables $2-4$. The trend of the $I_{\text {apatite }} / I_{\text {amide II }}$ ratio, see Figure $11 \mathrm{~A}$, showed that after $24 \mathrm{~h}$, a certain remineralization occurred, whilst no further apatite deposition was observed at two months.

\subsection{Control}

ESEM showed a uniform smear layer covering the tubules, see Figure $5 \mathrm{~d}$. After $24 \mathrm{~h}$ and two months the tubules were still closed.

EDX analysis showed high peaks of $\mathrm{P}, \mathrm{Ca}$, and $\mathrm{O}$, that slightly decrease after $24 \mathrm{~h}$ and two months. After the removal of the smear layer with distilled water, $\mathrm{Ca} / \mathrm{N}$ and $\mathrm{P} / \mathrm{N}$ ratios increased (from $0.83 \pm$ 
0.08 to $1.17 \pm 0.04$ and from $0.65 \pm 0.06$ to $0.82 \pm 0.03$ ). After $24 \mathrm{~h}$, both ratios slightly decreased, while increased after two months. The $\mathrm{Ca} / \mathrm{P}$ ratio increased after washing and then remained constant.

As expected, the treatment with water (T0) did not alter the IR spectrum, as shown in Figure 10, and thus the $I_{\text {apatite }} / I_{\text {amide II }}$ and $I_{1410 \text { (carbonate) }} / I_{554 \text { (phosphate) }}$ ratios also remained the same, see Figure 11. Interestingly, immersion in SBF for $24 \mathrm{~h}$ induced a strengthening of the apatite bands as well as of the $I_{\text {apatite }} / I_{\text {amide II }}$ ratio, see Figure $11 \mathrm{~A}$, suggesting a certain remineralization; the carbonate content of the B-type carbonated apatite decreased, as revealed by the decrease of the $I_{1410 \text { (carbonate) }} / I_{554 \text { (phosphate) }}$ ratio, see Figure $11 \mathrm{~B}$. No further changes in the two ratios were observed after aging for two months.

\section{Discussion}

In this study, ATR/IR spectroscopy was used as a sensitive non-destructive analytical method for the assessment of the mineral content variations on the dentine surface and collagen modifications after the use of EDTA and citric acid. Several techniques, such as XRD or mass spectroscopy, require destructive processes (such as the pulverization of samples), which make the analysis of the solely treated area unreliable. Moreover, XRD can only provide information regarding dentine mineral components. Different studies have compared the chelating action and effectiveness of citric acid solutions vs. EDTA solutions in removing the smear layer when used as root canal irrigants [34-38]. Two studies have analyzed organic and inorganic dentine tissues' modifications by FTIR [39,40], proving the suitability of this technique for the qualitative and semiquantitative analysis of biological samples. One study has analyzed the chemical degradation of ground dentine particles constituents (namely apatite and collagen) before and after irrigation with $2.5 \% \mathrm{NaOCl}$ and/or $17 \%$ EDTA using the FTIR technique [39], revealing a continuing apatite depletion (loss of phosphates) over a period of $24 \mathrm{~h}$ when only EDTA solution is used. This data is similar to the result obtained in the present study. Another study has investigated the demineralization effect of several concentrations of EDTA alone or in combination with $\mathrm{NaOCl}$ on bovine dentine slices using ATR-FTIR [40]. This study has reported a greater dentine demineralization at higher concentrations and time of treatment. However, both studies did not investigate dentine mineralization changes over longer times (i.e., two months). Again, the activity of residual chelating agents could significantly affect the tooth microstructure.

The IR spectra of all the treated dentine samples at T0 showed the weakening of the apatite bands, see Figures 6-9; however, it must be observed that the apatite bands did not disappear. This behavior suggests that demineralization was only partial and took place at a lower depth than that corresponding to the ATR sampling (i.e., $2 \mu \mathrm{m}$ ), differing from our previous studies in which dentine samples were treated with 17\% EDTA for $2 \mathrm{~h}$ [24]. This trend confirms that the application time of the solution is crucial in determining the decalcifying effect [15].

The $I_{\text {apatite }} / I_{\text {amide II }}$ ratio was found to decrease upon all the treatments, see Figure $11 \mathrm{~A}$; the treatment with 10\% citric acid solution and 10\% EDTA determined the highest \% decreases in this parameter and thus the most pronounced demineralization within the uppermost $2 \mu \mathrm{m}$ region investigated by ATR. The $\mathrm{Ca} / \mathrm{N}$ and $\mathrm{P} / \mathrm{N}$ ratios were also found to decrease upon all the treatments; however, only 10\% EDTA and 10\% citric acid solution induced significant changes in these parameters, in agreement with the IR findings.

The carbonate content of the B-type carbonated apatite was evaluated through the IR $I_{1410 \text { (carbonate) }} / I_{554 \text { (phosphate) }}$ ratio; it did not change significantly, see Figure $11 \mathrm{~B}$, upon all the treatments. This behavior suggests that the chelating agents removed apatite without altering the carbonate content of the phase that remained in the partially demineralized dentine sample. This result is in agreement with the recent findings on dentine slices treated for $1 \mathrm{~min}$ with differently concentrated EDTA solutions [28].

All the treatments, with the exception of 1\% EDTA, determined shifts in the collagen bands (i.e., Amide III, $\mathrm{COO}^{-}$modes and, in the case of $10 \%$ and 17\% EDTA, also Amide II, see Figures 7-9). The Amide bands, due to the repeating peptide unit of proteins, have been extensively used to study 
the secondary structure and conformational transitions of proteins; the observed changes suggest that the collagen network underwent a certain conformational rearrangement upon demineralization, although to a lower extent than that previously observed by treatment with 17\% EDTA for a longer

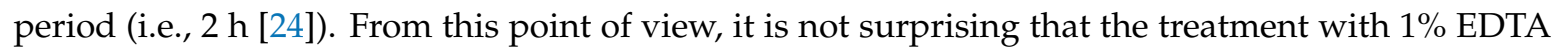
(i.e., the lowest investigated concentration) did not induce any effect on collagen conformation, see Figure 6. The shifts of the $\mathrm{COO}^{-}$collagen vibration may be ascribed to changes in the interactions between the collagen and apatite phases, according to the literature [41].

The concept of remineralization is based on the reincorporation of mineral (apatite) in dental tissues (dentine or enamel [24]). In the present study, looking at remineralization represents additional proof of the action of the chelating agents during the evaluation times. After $24 \mathrm{~h}$ of aging in SBF, IR spectroscopy showed that the $I_{\text {apatite }} / I_{\text {amide II }}$ increased, and thus remineralization occurred for all the samples, control included. Moreover, it must be observed that all the T24h samples were characterized by $I_{\text {apatite }} / I_{\text {amide II }}$ ratios which were significantly different (i.e., lower) with respect to the control sample, except that corresponding to the treatment with $1 \%$ EDTA, which had an $I_{\text {apatite }} / I_{\text {amide II }}$ comparable to the control sample, see Figure 11A. This result suggests that the treatment with $1 \%$ EDTA did not prevent remineralization and this sample behaved similarly to the control one, which, upon aging in SBF for $24 \mathrm{~h}$, remineralized to a certain extent. On the contrary, treatment with the other chelating agents hindered remineralization at this stage.

The IR analysis of the T24h sample previously treated with 1\% EDTA showed that the deposited inorganic phase was less crystalline than that present in the SL sample, as revealed by the higher width of the $v_{3} \mathrm{PO}_{4}{ }^{3-}$ band, see Figure 6; moreover, as suggested by the $I_{1410 \text { (carbonate) }} / I_{554 \text { (phosphate) }}$ value, see Figure 11B, it had a lower carbonate content, in agreement with the literature [25]. Analogous trends were observed for the control sample, see Figures 10 and 11B. On the basis of these results, it may be affirmed that the newly formed mineral layer on the surface of dentine is different from that of the smear layer.

After two months of aging, the $I_{\text {apatite }} / I_{\text {amide II }}$ ratio and thus the degree of remineralization significantly increased for all the samples, except those treated with $10 \%$ citric acid solution and $17 \%$ EDTA; in fact, all the samples except the latter two had $I_{\text {apatite }} / I_{\text {amide II }}$ ratios higher than the control sample that decreased along the series EDTA $1 \%>10 \%$ EDTA $>17 \%$ EDTA $>10 \%$ citric acid. It is interesting to note that the IR spectrum of the T2m sample previously treated with $1 \%$ EDTA did not show the Amide II and III bands, see Figure 6, suggesting that the deposited apatite phase was thicker than the sampling depth analyzed by ATR (i.e., $2 \mu \mathrm{m}$ ). Therefore, the obtained IR spectrum, shown in Figure 6, is mainly representative of the phase formed upon aging and allows information to be gained on its crystallinity and carbonate content; the width of the previously mentioned $v_{3} \mathrm{PO}_{4}{ }^{3-}$ band (which appeared at a wavenumber shifted to $992 \mathrm{~cm}^{-1}$ ) was higher than for the SL sample, suggesting that the inorganic phase was less crystalline; however, as suggested by the $I_{1410 \text { (carbonate) }} / I_{554 \text { (phosphate) }}$ value, shown in Figure 11B, it had a carbonate content similar to that present in the smear layer. The phase formed on the dentine sample previously treated with 10\% EDTA after two months was even less crystalline, see Figure 7, and contained a significantly lower amount of carbonate, as shown in Figure 11B. Upon treatment with citric acid, the mineral phase formed after two months was characterized by nearly the same carbonate content as the latter sample, see Figure 11B, but was more crystalline, see Figure 9; however, it must be observed that for this sample the spectral contribution of the underlying dentine is higher, due to the stronger relative intensity of its bands.

On the basis of the IR analyses, the remineralization extent was found to decrease along the series; EDTA $1 \%>10 \%$ EDTA $>17 \%$ EDTA $>10 \%$ citric acid. The ESEM/EDX data did not show a perfectly coincident trend, probably due to the different sampling areas of the two techniques. However, ESEM/EDX and IR spectroscopy were in agreement that the highest degree of remineralization was promoted by $1 \%$ EDTA and the lowest degree of remineralization was found after treatment with $10 \%$ citric acid. 
Based on these findings, remineralization was most greatly observed on samples treated with low concentrations (in particular, samples treated with 1\% EDTA), also showing lower collagen rearrangement. Differently, more concentrated solutions demonstrated a higher demineralization effect and higher collagen rearrangements. Demineralization and collagen rearrangement may have potential negative effects on root dentine and may play a negative effect on tooth longevity [42].

This effect may potentially have implications on the outcome of endodontic treatments and, therefore, the use of these solutions should be reconsidered. Further studies with more samples need to be performed to validate these results.

\section{Conclusions}

Key findings of this article may be summarized as follows:

- $\quad I_{\text {apatite }} / I_{\text {amide II }}$ and $\mathrm{Ca} / \mathrm{N}$ and $\mathrm{P} / \mathrm{N}$ ratios were reduced after 10 min of treatment with chelating agents, suggesting a demineralization of dentine (higher demineralization in $10 \%$ citric acid and lower in 17\% EDTA).

- No significant changes in $I_{1410 \text { (carbonate) }} / I_{554 \text { (phosphate) }}$ ratio were observed after $10 \mathrm{~min}$; chelating agents removed only apatite and not carbonate in the demineralized samples.

- Shift in collagen IR Amide II and III bands after treatment with 10\% EDTA, 17\% EDTA, and 10\% citric acid; the collagen network performed a rearrangement.

- $\quad I_{\text {apatite }} / I_{\text {amide II }}$ ratio increased after $24 \mathrm{~h}$ in SBF; a remineralization occurred in each sample; those treated with $1 \%$ EDTA had a similar ratio to the control group.

- $I_{1410 \text { (carbonate) }} / I_{554 \text { (phosphate) }}$ ratio decreased in $1 \%$ EDTA treated samples after $24 \mathrm{~h}$; there was a reduction in carbonate content.

- $\quad I_{\text {apatite }} / I_{\text {amide II }}$ ratio increased after two months from the treatment with $1 \%$ and $10 \%$ EDTA; Ca/N and $\mathrm{P} / \mathrm{N}$ ratios, in addition to increasing in previously mentioned treatments, also increased after treatment with 17\% EDTA. Results indicate dentine remineralization in all cases.

- Both ESEM/EDX and IR spectroscopy techniques revealed that treatment with 1\% EDTA yielded the highest remineralization, while treatment with $10 \%$ citric acid yielded the lowest.

Author Contributions: Conceptualization, M.G.G., C.P.; Data curation, A.P.; Formal Analysis, F.Z.; Funding Acquisition, C.P.; Investigation, P.T., A.P., F.Z.; Methodology, M.G.G., C.P.; Project Administration, M.G.G.; Supervision, C.P.; Validation, P.T.; Writing-Original Draft Preparation, P.T., A.P.; Writing-Review \& Editing, M.G.G., P.T., C.P., G.S.

Funding: This research has been supported with the academic funds of Carlo Prati.

Conflicts of Interest: The authors declare no conflict of interest.

\section{References}

1. Prati, C.; Selighini, M.; Ferrieri, P.; Mongiorgi, R. Scanning electron microscopic evaluation of different endodontic procedures on dentin morphology of human teeth. J. Endod. 1994, 20, 174-179. [CrossRef]

2. Foschi, F.; Nucci, C.; Montebugnoli, L.; Marchionni, S.; Breschi, L.; Malagnino, V.A.; Prati, C. SEM evaluation of canal wall dentine following use of Mtwo and ProTaper NiTi rotary instruments. Int. Endod. J. 2004, 37, 832-839. [CrossRef] [PubMed]

3. Pirani, C.; Pelliccioni, G.A.; Marchionni, S.; Montebugnoli, L.; Piana, G.; Prati, C. Effectiveness of three different retreatment techniques in canals filled with compacted gutta-percha or thermafil: A scanning electron microscope study. J. Endod. 2009, 35, 1433-1440. [CrossRef] [PubMed]

4. Pirani, C.; Feletti, G.; Cretti, R.; Acquaviva, G.L.; Marchionni, S.; Prati, C. SEM evaluation of root canal dentin morphology after Ni-Ti instrumentation. J. Appl. Biomater. Biomech. 2009, 7, 116-122. [PubMed]

5. Mader, C.L.; Baumgartner, J.G.; Peters, D.D. Scanning electron microscopic investigation of the smeared layer on root canal walls. J. Endod. 1984, 10, 477-483. [CrossRef] 
6. Wu, L.; Mu, Y.; Deng, X.; Zhang, S.; Zhou, D. Comparison of the effect of four decalcifying agents combined with $60{ }^{\circ} \mathrm{C} 3 \%$ sodium hypochlorite on smear layer removal. J. Endod. 2012, 38, 381-384. [CrossRef] [PubMed]

7. Hulsmann, M.; Heckendorff, M.; Lennon, A. Chelating agents in root canal treatment: Mode of action and indications for their use. Int. Endod. J. 2003, 36, 810-830. [CrossRef]

8. Haapasalo, M.; Endal, U.; Zandi, H.; Coil, J.M. Eradication of endodontic infection by instrumentation and irrigation solutions. Endod. Top. 2005, 10,77-102. [CrossRef]

9. Ulusoy, Ö.İ.; Görgül, G. Effects of different irrigation solutions on root dentin microhardness, smear layer removal and erosion. Aust. Endod. J. 2013, 39, 66-72. [CrossRef]

10. Goldman, L.B.; Goldman, M.; Kronman, J.H.; Lin, P.S. The efficacy of several irrigating solutions for endodontics: A scanning electron microscopic study. Oral Surg. Oral Med. Oral Pathol. 1981, 52, 197-204. [CrossRef]

11. Baumgartner, J.; Mader, C. A scanning electron microscopic evaluation of four root canal irrigation regimens. J. Endod. 1987, 13, 147-157. [CrossRef]

12. Wayman, B.E.; Kopp, W.M.; Pinero, G.J.; Lazzari, E.P. Citric and lactic acids as root canal irrigants in vitro. J. Endod. 1979, 5, 258-265. [CrossRef]

13. Scelza, M.F.; Antoniazzi, J.H.; Scelza, P. Efficacy of final irrigation: A scanning electron microscopic evaluation. J. Endod. 2000, 26, 355-358. [PubMed]

14. Machado-Silveiro, L.F.; Gonzalez-Lopez, S.; Gonzalez-Rodriguez, M.P. Decalcification of root canal dentin by citric acid, EDTA and sodium citrate. Int. Endod. J. 2004, 37, 365-369. [CrossRef] [PubMed]

15. Pérez-Heredia, M.; Ferrer-Luque, C.M.; González-Rodríguez, M.P.; Martín-Peinado, F.J.; González-López, S. Decalcifying effect of $15 \%$ EDTA, $15 \%$ citric acid, $5 \%$ phosphoric acid and $2.5 \%$ sodium hypochlorite on root canal dentin. Int. Endod. J. 2008, 4, 418-423. [CrossRef] [PubMed]

16. Anderson, D.A.; Bowen, R.L.; Eick, J.D.; Henderson, D.A. Smear layer removal and bonding consideration. Oper. Dent. 1984, 3, 30-34.

17. Cooke, H.G.; Grower, M.F.; Del Rio, C. Effects of instrumentation with a chelating agent on the periapical seal of obturated root canals. J. Endod. 1976, 2, 312-314.

18. Biesterfeld, R.C.; Taintor, J.F. A comparison of periapical seals of root canals with RC-Prep or Salvizol. Oral Surg. Oral Med. Oral Pathol. 1980, 49, 532-537. [CrossRef]

19. Mountouris, G.; Silikas, N.; Eliades, G. Effect of sodium hypochlorite treatment on the molecular composition and morphology of human coronal dentin. J. Adhes. Dent. 2004, 6, 175-182.

20. Eliades, G.; Mantzourani, M.; Labella, R.; Mutti, B.; Sharma, D. Interactions of dentin desensitisers with human dentin: Morphology and composition. J. Dent. 2013, 41, 28-39. [CrossRef]

21. Liu, Y.; Yao, X.; Liu, Y.; Wang, Y. A fourier transform infrared spectroscopy analysis of carious dentin from transparent zone to normal zone. Caries Res. 2014, 48, 320-329. [CrossRef] [PubMed]

22. Gandolfi, M.G.; Taddei, P.; Siboni, F.; Modena, E.; De Stefano, E.D.; Prati, C. Biomimetic remineralization of human dentin using promising innovative calcium-silicate hybrid "smart" materials. Dent. Mater. 2011, 27, 1055-1069. [CrossRef] [PubMed]

23. Gandolfi, M.G.; Iezzi, G.; Piattelli, A.; Prati, C.; Scarano, A. Osteoinductive potential and bone-bonding ability of ProRoot MTA, MTA Plus and Biodentine in rabbit intramedullary model: Microchemical characterization and histological analysis. Dent. Mater. 2017, 3, 221-238. [CrossRef] [PubMed]

24. Taddei, P.; Prati, C.; Gandolfi, M.G. A poly (2-hydroxyethyl methacrylate)-based resin improves the dentin remineralizing ability of calcium silicates. Mater. Sci. Eng. C 2017, 77, 755-764. [CrossRef] [PubMed]

25. Zhang, X.; Neoh, K.G.; Lin, C.C.; Kishen, A. Remineralization of partially demineralized dentin substrate based on a biomimetic strategy. J. Mater. Sci. Mater. Med. 2012, 23, 733-742. [CrossRef] [PubMed]

26. Belbachir, K.; Noreen, R.; Gouspillou, G.; Petibois, C. Collagen types analysis and differentiation by FTIR spectroscopy. Anal. Bioanal. Chem. 2009, 395, 829-837. [CrossRef] [PubMed]

27. Muscariello, L.; Rosso, F.; Marino, G.; Giordano, A.; Barbarisi, M.; Cafiero, G.; Barbarisi, A. A critical overview of ESEM applications in the biological field. J. Cell Physiol. 2005, 205, 328-334. [CrossRef]

28. Bergmans, L.; Moisiadis, P.; Van Meebeek, B.; Quirynen, M.; Lambrechts, P. Microscopic observation of bacteria: Review highlighting the use of environmental SEM. Int. Endod. J. 2004, 38, 775-788. [CrossRef]

29. Gandolfi, M.G.; Farascioni, S.; Pashley, D.H.; Gasparotto, G.; Carlo, P. Calcium silicate coating derived from Portland cement as treatment for hypersensitive dentine. J. Dent. 2008, 36, 565-578. [CrossRef] 
30. Sauro, S.; Gandolfi, M.G.; Prati, C.; Mongiorgi, R. Oxalate-containing phytocomplexes as dentine desensitisers: An in vitro study. Arch. Oral. Biol. 2006, 51, 655-664. [CrossRef]

31. Nelson, D.G.A.; Featherstone, J.D. Preparation, analysis, and characterization of carbonated apatites. Calcif. Tissue Int. 1982, 34, S69-S81. [PubMed]

32. Featherstone, J.D.; Pearson, S.; LeGeros, R.Z. An infrared method for quantification of carbonate in carbonated apatites. Caries Res. 1984, 18, 63-66. [CrossRef] [PubMed]

33. Krajewski, A.; Ravaglioli, A.; Tinti, A.; Taddei, P.; Mazzocchi, M.; Martinetti, R.; Fagnano, C.; Fini, M. Comparison between the in vitro surface transformations of AP40 and RKKP bioactive glasses. J. Mater. Sci. Mater. Med. 2005, 16, 119-128. [CrossRef] [PubMed]

34. Yamada, R.S.; Armas, A.; Goldman, M.; Lin, P.S. A scanning electron microscopic comparison of a high volume final flush with several irrigating solutions: Part 3. Int. Endod. J. 1983, 9, 137-142. [CrossRef]

35. Harashima, T.; Kimura, Y.; Matsumoto, K.; Takeda, F.H. A comparative study of the removal of smear layer by three endodontic irrigants and two types of laser. Int. Endod. J. 1999, 32, 32-39.

36. Khedmat, S.; Shokouhinejad, N. Comparison of the efficacy of three chelating agents in smear layer removal. J. Endod. 2008, 34, 599-602. [CrossRef] [PubMed]

37. Prado, M.; Gusman, H.; Gomes, B.P.; Simão, R.A. Scanning electron microscopic investigation of the effectiveness of phosphoric acid in smear layer removal when compared with EDTA and citric acid. J. Endod. 2011, 37, 255-258. [CrossRef]

38. Tuncer, A.; Tuncer, S. Effect of different final irrigation solutions on dentinal tubule penetration depth and percentage of root canal sealer. J. Endod. 2012, 38, 860-863. [CrossRef]

39. Ramírez-Bommer, C.; Gulabivala, K.; Ng, Y.L.; Young, A. Estimated depth of apatite and collagen degradation in human dentine by sequential exposure to sodium hypochlorite and EDTA: A quantitative FTIR study. Int. Endod. J. 2018, 51, 469-478. [CrossRef]

40. Tartari, T.; Bachmann, L.; Zancan, R.F.; Vivan, R.R.; Duarte, M.A.H.; Bramante, C.M. Analysis of the effects of several decalcifying agents alone and in combination with sodium hypochlorite on the chemical composition of dentin. Int. Endod. J. 2017, 51, 42-54. [CrossRef]

41. Sionkowska, A.; Kozłowska, J. Characterization of collagen/hydroxyapatite composite sponges as a potential bone substitute. Int. J. Biol. Macromol. 2010, 47, 483-487. [CrossRef] [PubMed]

42. Prati, C.; Pirani, C.; Zamparini, F.; Gatto, M.R.; Gandolfi, M.G. A 20-year historical prospective cohort study of root canal treatments. A Multilevel analysis. Int. Endod. J. 2018, 51, 955-968. [CrossRef] [PubMed] 